\title{
Uma "sociedade do espetáculo" nos/dos estudos organizacionais brasileiros: notas críticas sobre uma leitura incipiente
}

\author{
Una "sociedad del espectáculo" en/de los estudios organizacionales brasileños: notas \\ críticas acerca de una lectura incipiente
}

\section{A "society of the spectacle" in/of the Brazilian organizational studies: critical notes on an incipient reading}

\author{
Pablo Gobira ${ }^{1}$ \\ Universidade do Estado de Minas Gerais / Escola Guignard, Belo Horizonte - MG, Brasil \\ Oscar Lima ${ }^{2}$ \\ Universidade Federal de Minas Gerais / Faculdade de Ciências Econômicas, Centro de Pós-Graduação e Pesquisas em Administração, Belo \\ Horizonte - MG, Brasil \\ Alexandre Carrieri ${ }^{3}$ \\ Universidade Federal de Minas Gerais / Faculdade de Ciências Econômicas, Centro de Pós-Graduação e Pesquisas em Administração, Belo \\ Horizonte - MG, Brasil
}

\section{Resumo}

Este artigo analisa a recepção de Guy Debord na Administração. Para isso, recorre à teoria crítica do autor com o intuito de explorar as formas como os pesquisadores da área estão incorporando o pensamento do teórico francês em seus trabalhos. Com trabalhos científicos em mãos e em referência à tradição crítica ocidental, inaugurada nas primeiras décadas do século XX, apresentamos os limites e possibilidades dessas apropriações na Administração, com o intuito de abrir possibilidades de pesquisa com um ensaísta tão pouco explorado. Entendemos que a teoria crítica sobre a sociedade do espetáculo, ao contrário do que tem sido feito nos estudos organizacionais, e a leitura de alguns intelectuais latino-americanos, não se resume somente aos estudos culturais. Nesse sentido, a forma de adotar Debord e sua crítica na Administração serve como crítica à Administração, tal como se critica todo o espetáculo.

Palavras-chave: Teoria crítica. Espetáculo. Marxismo. Estudos organizacionais.

Artigo submetido em 31 de janeiro de 2014 e aceito para publicação em 24 de novembro de 2014.

DOI: http://dx.doi.org/10.1590/1679-395115868

${ }^{*}$ Agradecemos ao CNPq o financiamento da pesquisa.

${ }^{1}$ Doutor em Literatura Comparada pela Universidade Federal de Minas Gerais - UFMG; Professor da Escola Guignard - Universidade do Estado de Minas Gerais - UEMG. Endereço: Rua Ascânio Burlamarque, 540, Mangabeiras, CEP 30315-030, Belo Horizonte-MG, Brasil. E-mail: pablo.o.gobira@gmail.com

2 Doutorando em Administração pela Universidade Federal de Minas Gerais - UFMG; Membro do NEOS - Núcleo de Estudos Organizacionais e Sociedade do Departamento de Ciências Administrativas - UFMG. Endereço: Av. Antonio Carlos, 6627 - Edifício FACE - Sala 4071, Campus Pampulha, CEP 31270-901, Belo Horizonte-MG, Brasil. E-mail: lima.oscar@gmail.com.br

${ }^{3}$ Doutor em Administração pela Universidade Federal de Minas Gerais - UFMG; Professor Adjunto da UFMG - Faculdade de Ciências Econômicas / Centro de Pós-Graduação e Pesquisas em Administração; Coordenador do NEOS - Núcleo de Estudos Organizacionais e Sociedade do Departamento de Ciências Administrativas - UFMG. Endereço: Av. Antonio Carlos, 6627 - Edifício FACE - Sala 4071, Campus Pampulha, CEP: 31270-901, Belo Horizonte-MG, Brasil. E-mail: alexandre@face.umg.br 


\title{
Resumen
}

Este artículo analiza la recepción de Guy Debord en la Administración. Para ello, se refiere a la teoría crítica del autor con el fin de explorar las formas en que los investigadores del área están incorporando el pensamiento del teórico francés en sus trabajos. Con artículos científicos en las manos y en referencia a la tradición crítica occidental, inaugurada en las primeras décadas del siglo XX, presentamos los límites y las posibilidades de estas apropiaciones en la Administración, con el fin de abrir las posibilidades de investigación con un ensayista tan poco explorado. Creemos que la teoría crítica acerca de la sociedad del espectáculo, al contrario de lo que se ha hecho en los estudios organizacionales, y la lectura de algunos intelectuales latinoamericanos, no se limita sólo a los estudios culturales. En este sentido, la forma de adoptar Debord y su crítica en la Administración sirve como una crítica a la Administración, así como todo el espectáculo es criticado.

Palabras clave: Teoría crítica. Espectáculo. Marxismo. Estudios organizacionales.

\begin{abstract}
This article analyzes the reception of Guy Debord in Administration. For this, it resorts to the author's critical theory in order to explore the ways how researchers in the field have been incorporating the French theorist's thought in their works. With scientific papers in hands and referring to the Western critical tradition inaugurated in the first decades of the $20^{\text {th }}$ century, we introduce the limits and possibilities of these assumptions in Administration, in order to open up research possibilities with such a little-known essayist. We think that critical theory on the society of the spectacle, contrary to what has been done in organizational studies, and the reading by some Latin American intellectuals, is not restricted only to cultural studies. Thus, the way how to adopt Debord and his criticism in Administration is useful as a criticism to Administration just as the whole spectacle is criticized.
\end{abstract}

Keywords: Critical theory. Spectacle. Marxism. Organizational studies.

\section{Introdução}

Este artigo é proposto devido à necessidade da recepção de teóricos e críticos ainda não explorados na área da Administração e, em especial, dos estudos organizacionais. Com a ampliação da área e a constante busca por novas matrizes teóricas e variados diálogos, alguns autores passam a ser descobertos, redescobertos ou até modelados sob "novos" interesses. Nesse movimento, muito dos trabalhos nos estudos organizacionais, mesmo que indiretamente, passa a se basear na recepção de outras áreas. Muitas vezes, essa recepção tenderá a um ou outro caminho de leitura que, como se verá neste artigo, pode não se desenvolver em um terreno estável.

Por entendermos a instabilidade como um risco ao incremento da área, propomos, aqui, a discussão de um autor cuja teoria é passível de ser incorporada nos debates dos estudos organizacionais e, também, na área da Administração. A ideia de estabilidade compreende uma coerência da recepção da obra do autor e não corresponde a leitura exegética, displicente, ou em oposição. Esta será uma leitura derivada do pensamento da obra teórica do autor, desenvolvida longe dos ditames impessoais e objetivos das publicações especializadas.

Discutimos um autor que apresenta diversos caminhos de leitura ainda não estáveis na academia, responsáveis por ditar tendências variadas que se desprendem das propostas concretas de sua teoria, teimando tratar da realidade organizacional e social. O estilo e o tom deste texto buscam mostrar, por si sós, a diversidade de leituras possíveis. Essa foi nossa solução para abordar o pensamento de Debord, diante da impossibilidade de discutir alguns conceitos situacionistas, como desvio/détournement e deriva, ligados a um tempo e espaço que não é o da academia, mas da estratégia, isto é, uma dimensão da teoria crítica do espetáculo. Em nosso entendimento, se eles se fundam no princípio de ação fora da linguagem do espetáculo, 
não caberia discuti-los na Administração - se são praticados como espetáculo, deveríamos chamá-los de outra coisa.

Guy Debord é responsável pela difusão da teoria crítica acerca da sociedade do espetáculo. Obviamente, a designação da sociedade do século XX como "espetacular" não foi privilégio ou invenção do autor francês. Considerar a sociedade espetacular tornou-se comum após o advento e a popularização das máquinas que captavam e, posteriormente, projetavam imagens. Primeiro, a câmera fotográfica, no século XIX, depois a propagação do cinema e da televisão, no século XX, proporcionaram uma inundação de imagens na sociedade. Portanto, falar de espetáculo nos dez anos posteriores à Segunda Guerra Mundial era algo comum. Fazer a crítica da proliferação de imagens, de sua banalização, da manipulação das pessoas por meio das imagens ou mesmo da vigilância era, nessa época, necessário. O que não se tornou comum foi a "teoria crítica da sociedade do espetáculo", o que significa uma efetiva negação de todas as instâncias do espetáculo na sociedade.

Por isso, este artigo propõe uma discussão a partir de Guy Debord, apresentando as potencialidades de diálogo entre os estudos organizacionais e seu pensamento e procurando desenvolver um caminho com o mínimo de instabilidades ou incoerências. Com isso em vista, este artigo é organizado em cinco seções, além da introdução e das considerações finais. A primeira delas apresenta os principais pontos da teoria crítica, tal como foi concebida originalmente por Horkheimer (1983b), em seu ensaio "Teoria tradicional e teoria crítica". A segunda resume o que é a crítica da sociedade do espetáculo, para que o leitor perceba de onde partimos. A terceira apresenta um panorama da recepção crítica de Guy Debord. A quarta propõe analisar artigos que fazem referência (citação ou alusão) ao autor ou à sociedade do espetáculo na área da Administração. Por fim, apresentamos, de maneira sucinta, algumas formas pelas quais o crítico francês pode ser trazido para discussões nos estudos organizacionais.

\section{A Teoria Crítica}

Apesar de estar ligada a determinada tradição de pensamento que congrega diferentes autores, a expressão teoria crítica [Kritische Theorie], tal como é conhecida hoje, décadas depois dos movimentos sociais de protesto da Alemanha terem voltado-se para ela, surgiu pela primeira vez em um texto de 1937, intitulado "Teoria tradicional e teoria crítica" de Max Horkheimer (1895-1973). Esse texto foi publicado na Zeitschrift für Sozialforschung [Revista de Pesquisa Social], publicação oficial do Institut für Sozialforschung [Instituto de Pesquisa Social], fundado em 1923, que foi editada de 1932 a 1942 pelo próprio Horkheimer. Foi com a finalidade de divulgar a produção do círculo de intelectuais do instituto, do qual foi diretor de 1930 a 1958 , que Horkheimer fundou a Zeitschrift für Sozialforschung. Desse modo, quanto à sua origem, a expressão teoria crítica está ligada a um instituto, a uma revista, a um pensador no centro de ambos (Horkheimer), no contexto do nazismo (1933-45), do stalinismo (1924-53) e da Segunda Guerra Mundial (1939-45) (NOBRE, 2004; 2008; JAY, 1996; WIGGERSHAUS, 1998).

Foi Max Horkheimer que desenhou um programa de investigação e funcionamento do instituto, com base no trabalho coletivo interdisciplinar, em um momento de aprofundamento da especialização, da autonomia e da independência das ciências humanas, ainda que sem qualquer previsão de integração entre a filosofia e a pesquisa empírica (HONNETH, 1999). Contra isso, a valorização da especialização veio acompanhada de certa unidade, garantida pela referência à obra de Karl Marx (1818-1883), dando a essa experiência inovadora o nome de materialismo interdisciplinar (NOBRE, 1996; HONNETH, 1999). Tal projeto metodológico, mesmo que esboçado por outros intelectuais (JAY, 1984), encontrou seu representante mais capaz em Horkheimer, que era suficientemente "positivista", para valorizar as ciências especializadas (HONNETH, 1999), e cuidadoso, para diferenciar seu projeto do puro ativismo partidário (FREITAG, 2004).

No diagnóstico de "Teoria tradicional e teoria crítica", Nobre (2001) destaca sua proximidade a outro diagnóstico realizado em 1923, por Lukács (2003), em História e consciência de classe. Para Lukács, no 
capitalismo, a totalidade concreta da sociedade (classes sociais, modo de produção etc.) não é percebida pelo pensamento burguês como produto da ação humana. Vejamos uma passagem onde ele explica isso:

Os objetos da história aparecem como objetos de leis naturais e imutáveis, eternas. A história se fixa num formalismo incapaz de conceber as formações sócio-históricas em sua essência verdadeira como relações entre homens; elas são, antes, afastadas por uma distância intransponível dessas mais autênticas fontes de compreensão da história (LUKÁCS, 2003, p. 137, grifo do autor).

Ou seja, a crítica a essa percepção da ciência enquanto falsa práxis pode ser encontrada tanto nos textos de Horkheimer como nos de Lukács.

Assim, não foram tanto seus princípios teóricos, mas seus objetivos metodológicos, resultantes de um reconhecimento franco e programático das ciências especializadas (economia política, psicologia, crítica cultural, etc.) que distinguiram a teoria crítica das outras numerosas tentativas empreendidas no período de renovação do marxismo. Nesse sentido, o termo teoria crítica também demarca um campo teórico no qual a pluralidade de modelos críticos desenvolvidos a partir da obra de Marx é estimulada em seu interior, em contraposição à tradição de cientificismo inaugurada por René Descartes (1596-1650) e que atravessava toda a modernidade. Como ele mesmo afirmou:

Em meu ensaio "Teoria Tradicional e Teoria Crítica" apontei a diferença entre dois métodos gnosiológicos. Um foi fundamentado no Discours de La Méthode, cujo jubileu de publicação se comemorou neste ano [1937], e outro na crítica da economia política. A teoria em sentido tradicional, cartesiano, como a que se encontra em vigor em todas as ciências especializadas, organiza a experiência à base da formulação de questões que surgem em conexão com a reprodução da vida dentro da sociedade atual. Os sistemas das disciplinas contêm os conhecimentos de tal forma que, sob circunstâncias dadas, são aplicáveis ao maior número possível de ocasiões. A gênese social dos problemas, as situações reais, nas quais a ciência é empregada e os fins perseguidos em sua aplicação, são por ela mesma consideradas exteriores. - A teoria crítica da sociedade, ao contrário, tem como objeto os homens como produtores de todas as suas formas históricas de vida. As situações efetivas, nas quais a ciência se baseia, não são para ela uma coisa dada, cujo único problema estaria na mera constatação e previsão segundo as leis da probabilidade. O que é dado não depende apenas da natureza, mas também do poder do homem sobre ele. Os objetos e a espécie de percepção, a formulação de questões e o sentido da resposta dão provas da atividade humana e do grau de seu poder (HORKHEIMER, 1983a, p. 155, grifo do autor).

A diferenciação entre dois métodos gnosiológicos foi uma necessidade, uma vez que, para Horkheimer, era problemático fazer ciência sem antes dar atenção ao conceito de "teoria" e ao modo como era realizado o processo de pesquisa. A seu ver, academicamente, havia muitas discussões quanto aos caminhos para seguir o modelo (Vorbild), sem que este ou seu processo de concepção (Auffassung) fossem debatidos. Tal fato permitia que um modelo de entendimento pudesse ser utilizado para igualar metodologicamente fenômenos sociais e fenômenos naturais, deixando os primeiros tão demonstráveis, previsíveis e calculáveis quanto os segundos:

De qualquer maneira existe uma identidade na concepção (Auffassung) de teoria entre as diferentes escolas sociológicas e entre estas e as ciências naturais. Os empíricos não têm outra representação melhor que os teóricos. Estão meramente convencidos de que, em vista da complexidade dos problemas sociais e do quadro atual da ciência, o trabalho com princípios gerais deve ser considerado como ocioso e cômodo. Na medida em que seja 
necessária a realização do trabalho teórico, isso ocorrerá, pensam eles, através do manuseio crescente do material; não é de se esperar a curto prazo exposições teóricas de grande alcance (HORKHEIMER, 1983b, p. 119).

A deficiência da moderna compreensão da teoria em geral tem como fundo a divergência entre pesquisa empírica e pensamento filosófico. A última tradição teórica em que ambas vertentes se fundiam em um único modo de pensamento, de modo que a análise empírica da realidade coincidia com a concepção filosóficohistórica da razão, foi a filosofia da história de Georg W. F. Hegel (1770-1831). Contudo, no decorrer do século XIX, tanto as premissas idealistas dessa filosofia como o vínculo que unia a pesquisa empírica e a filosofia se dissolveram. Sem mediação, as duas vertentes dessa filosofia da história foram incorporados no novo positivismo, onde o conhecimento empírico da realidade estava separado de qualquer autoconfirmação filosófica, resumindo-se à busca de fatos; e na metafísica de autores como Nicolai Hartman e Max Scheler, onde a reflexão da razão, sem referência teórica à realidade histórico-empírica, não ultrapassa a especulação sobre a essência (HONNETH, 1999).

Portanto, o desenvolvimento do pensamento pós-hegeliano levou a uma situação intelectual de que, na teoria da sociedade, não havia lugar para a ideia de razão historicamente incorporada e nem para a crítica transcendente. Desse modo, a teoria da sociedade não possuía meios cognitivos para medir as relações dadas em uma sociedade pela ideia transcendental de razão. A superação da cissura entre pesquisa empírica e filosofia coube, portanto, à nova proposta de teoria crítica da sociedade. Foi o que se deu nos textos de Horkheimer que, epistemologicamente, a partir da teoria do conhecimento materialista da primeira fase de Marx, voltou-se à crítica do positivismo e, metodologicamente, voltou-se a um conceito de pesquisa interdisciplinar (HONNETH, 1999).

Horkheimer partiu do pressuposto de que as ciências empíricas, por meio de sua metodologia, são determinadas pelas demandas do trabalho social; aqui, a verificação das proposições teóricas se subordina ao interesse de dominação da natureza (evidenciado já na obra Novum Organum [1620], de Francis Bacon), que é o mesmo interesse do trabalho, com a diferença de que este se guia em um nível pré-científico. Tão logo se clarifique esse contexto prático e constitutivo das ciências, evidencia-se o equívoco do positivismo: ao justificar as ciências somente no nível metodológico, ele se desvincula tanto da consciência de suas próprias origens societárias como do conhecimento de seus objetivos práticos que, como vimos, são bem diferentes da práxis social:

Tanto quanto a influência do material sobre a teoria, a aplicação da teoria sobre o material não é apenas um processo intracientífico, mas também um processo social. Afinal a relação entre hipóteses e fatos não se realiza na cabeça dos cientistas, mas na indústria. As regras como, por exemplo, a de que o alcatrão hulha quando submetido a determinadas reações desenvolve um corante, ou a de que a nitroglicerina, o salitre e outros elementos possuem grande força explosiva, constituem um saber acumulado que é aplicado efetivamente aos fatos no interior das fábricas dos grandes trustes (HORKHEIMER, 1983b, p. 122).

A origem do desprezo pela estrutura prática das teorias, que permite às ciências aparecerem como uma empresa pura, desvinculada de interesses práticos, estaria em Descartes. Teoria Tradicional é o nome dessa tradição de cientificismo, cujo objetivo é o conhecimento puro, ao invés da ação. A tarefa dessa concepção gnosiológica é estabelecer os vínculos necessários entre os fenômenos a partir da formulação de princípios gerais, coerentes e descritivos do mundo. Isso vale se esses princípios são gerados dedutivamente, como na teoria cartesiana; indutivamente, como na obra de John Stuart Mill; ou fenomenologicamente, como na filosofia de Edmund Husserl. Vale também para a ciência anglo-saxônica, que enfatiza o empirismo e a verificação e está sempre à procura de proposições gerais para testar. O que varia, diz ele, "é a posição filosófica do lógico" (HORKHEIMER, 1983b, p. 118). 
Entretanto, para que o modelo tradicional de teoria das ciências naturais seja transposto com sucesso para as ciências humanas, algumas separações são necessárias (NOBRE, 2004). Em primeiro lugar, devem-se separar no sujeito os papéis de cientista social (ou observador) de agente social, mesmo que ambos coexistam nele enquanto membro de uma sociedade. Em segundo lugar, é preciso distinguir a observação do funcionamento social, de uma avaliação da observação feita a partir dos valores próprios de cada cientista enquanto agente social. Ou seja, se, nas ciências humanas, o sujeito-cientista que pretende entender a sociedade é também objeto da investigação (enquanto participante da sociedade), essas duas facetas do mesmo indivíduo (os domínios do conhecimento e da ação) devem ser separadas, pois não cabe ao cientista qualquer valoração pessoal do objeto de estudo ou qualquer objetivo prático em sua pesquisa. Caso contrário, esse sujeito corre o risco de não ser reconhecido pelos seus pares como um cientista que produz conhecimento, mas como um agente social que defende uma concepção de mundo.

Com os mesmos critérios aplicados às ciências humanas, a teoria tradicional também estabelece uma especialização das ciências humanas de modo análogo às ciências da natureza: tem-se uma disciplina científica quando se consegue circunscrever um ramo de investigação da sociedade apartado de qualquer valoração de seu objeto (NOBRE, 2004). Foram esses parâmetros que deram origem a novas disciplinas científicas à época (sociologia, antropologia social e política), além de reorientar disciplinas já existentes (história, psicologia, direito).

À teoria tradicional Horkheimer opunha a teoria crítica, entendida como uma teoria sempre ciente de seu contexto social de origem e de seu contexto de aplicação prática (HONNETH, 1999). Todavia, o estabelecimento de uma teoria crítica da sociedade exigia uma reflexão sobre o nível histórico-filosófico para além da divisão contemporânea entre filosofia e as ciências, a fim de que essa reflexão fosse incorporada como o momento seguinte à pesquisa social empírica. Ou seja, a teoria crítica só conseguiria cumprir sua tarefa se, epistemologicamente, tivesse à disposição uma teoria da história que esclarecesse sua circunstância e seu papel no processo histórico.

Segundo Honneth (1999), os rudimentos dessa teoria da história estavam na versão marxista da história, segundo a qual o desenvolvimento das relações sociais de produção e do domínio técnico sobre a natureza torna-se determinante da mudança societária. A teoria crítica é incluída nesse evento histórico, não para legitimar o processo de trabalho, mas, sim, para se tornar uma "autoridade crítica no autoconhecimento social" (HONNETH, 1999, p. 509). Sua inclusão no estágio da produção e da técnica tem como referência as possibilidades da razão presentes nas forças produtivas - cuja tarefa da teoria é trazê-las a consciência:

[A teoria crítica] na formação de suas categorias e em todas as fases de seu desenvolvimento, segue conscientemente o interesse por uma organização racional da atividade humana: clarificar e legitimar esse interesse é a tarefa que ela confere a si própria (HORKHEIMER, 1983a, p. 156).

Assim, se a história avança de modo que o potencial para a razão (incorporado nas forças produtivas) seja liberado nas novas formas de organização e nos conflitos sociais, cabe à teoria identificar, na conjuntura singular do presente, na etapa atual da realização da razão, quais são os mecanismos impeditivos contra essas transformações. O reconhecimento e a condenação simultâneos da realidade do presente permitem uma crítica da razão no sentido kantiano, mas aplicada aos limites da racionalidade que naturaliza o processo social:

A razão não pode tornar-se, ela mesma, transparente enquanto os homens agem como membros de um organismo irracional. Como uma unidade naturalmente crescente e decadente, o organismo não é para a sociedade uma espécie de modelo, mas sim uma forma apática do ser, da qual tem que se emancipar (HORKHEIMER, 1983b, p. 131). 
Para Nobre (2004) a importância que a teoria adquire no campo crítico dá a ela dois elementos para a sua compreensão: um em sentido amplo e outro em sentido estrito. Em sentido amplo, a teoria crítica designa o campo do marxismo, que é anterior à conceituação de Horkheimer e possui elementos teóricos fundamentais a ser considerados pelo autor na diferenciação de outras teorias ("força de trabalho", "modo de produção", "mais-valia" etc.). Em sentido restrito, Horkheimer apresenta sua interpretação do pensamento marxiano, utilizando esses parâmetros interpretativos para analisar o momento histórico no qual escreve seu ensaio. Resultam disso três observações de seu tempo presente: o reconhecimento da passagem do capitalismo concorrencial para o monopolista; a diferenciação interna ao proletariado, que não empobreceu como previu Marx, mas teve uma pequena melhoria nas condições de vida; e a ascensão do totalitarismo corroborada pelos meios de comunicação de massa.

Assim, se "O Capital em suas análises não é menos exato que a economia política criticada" (HORKHEIMER, 1983a, p. 157), a referência à obra de Marx não significa tomá-la enquanto doutrina acabada, mas enquanto um conjunto de questionamentos norteadores a ser atualizado segundo uma constelação histórica específica. Ou seja, pode-se considerar tradicional tudo aquilo que perde seu sentido crítico com o tempo; mas nem tudo que é considerado crítico é destituído de um caráter tradicional.

Quanto a isso, cabe identificar, aqui, dois princípios fundamentais que a teoria crítica herdou de Marx, também apontados por Nobre (2004). O primeiro é sua orientação para a emancipação. A teoria não mais se limita a explicar o funcionamento das coisas, em uma cadeia de causa e efeito. A partir da realização do novo (que se insinua no existente, mas ainda não é), ela faz o diagnóstico das contradições do presente e os prognósticos do futuro. O curso dos acontecimentos, que é resultado das ações contra a estrutura vigente, confirma ou não os prognósticos teoréticos. Note-se que a prática não significa mera aplicação da teoria: ao envolver embates e conflitos, ela se converte em um momento da teoria, que utilizará os resultados dessas ações na verificação de novas hipóteses. No fim, é a perspectiva da emancipação que possibilita à teoria compreender as dinâmicas societárias em seu conjunto, longe das ilusões do capitalismo (liberdade dos sujeitos econômicos, autonomia da ciência diante da práxis, imutabilidade dos processos sociais etc.) e das insuficiências da teoria tradicional. Contra isso, a perspectiva da emancipação toma como horizonte "a transformação do todo, [que] pode servir-se sem dúvida do trabalho teórico, tal como ocorre dentro da ordem desta realidade existente. Contudo, ele dispensa o caráter pragmático que advém do pensamento tradicional como um trabalho profissional socialmente útil” (HORKHEIMER, 1983b, p. 131).

O segundo princípio fundamental da teoria crítica é o comportamento crítico. Uma vez que a teoria deve examinar o mundo social a partir da carência do que existe das possibilidades melhores nele embutidas, mas não realizadas, essa orientação exige que a teoria exprima um comportamento crítico tanto em relação ao conhecimento produzido sob o capitalismo (a teoria tradicional) como à realidade societária que é o objeto de estudo de tal conhecimento.

Para os sujeitos do comportamento crítico, o caráter discrepante cindido do todo social, em sua figura atual, passa a ser contradição consciente. Ao reconhecer o modo de economia vigente e o todo cultural nele baseado como produto do trabalho humano, e como a organização de que a humanidade impôs a si na mesma época atual, aqueles sujeitos que se identificam, eles mesmos, com esse todo e o compreendem como vontade e razão: ele é o seu próprio mundo (HORKHEIMER, 1983b, p. 130).

Mesmo que sob a perspectiva do comportamento crítico Horkheimer não negue que conhecer e agir sejam distintos, ele acredita que ambos devem ser tomados conjuntamente. Se a realidade social é resultado da ação humana e a ação humana se dá no contexto de estruturas sócio-históricas determinadas, cabe à teoria investigar essas estruturas para descobrir as condições para a ação. Sem essa investigação, a teoria permanecerá na superfície dos fenômenos e a percepção do cientista nas categorias sociais das quais ele não consegue se libertar. Contra esse risco, é importante que ambos reconheçam o exercício da ciência como um dos momentos da sociedade capitalista (dividida em classes, produtora de mercadorias etc.) e os dualismos 
que ela promove (fatos e valor, saber e agir, conhecimento e interesse etc.) como produtos da história dessa organização social. Afinal, essas separações têm influência até na percepção do cientista social mais "objetivo" (intuitivo ou positivista), para quem Horkheimer endereça o seguinte recado:

Em relação a isso poder-se-ia inverter a frase: as ferramentas são prolongamentos dos órgãos humanos, na frase: os órgãos são também prolongamentos das ferramentas. Nas etapas mais elevadas da civilização a práxis humana consciente determina inconscientemente não apenas o lado subjetivo da percepção, mas em maior medida o objeto. O que o membro da sociedade capitalista vê diariamente à sua volta: conglomerados habitacionais, fábricas, algodão, gado de corte, seres humanos, e não só estes objetos como também os movimentos, nos quais são percebidos, de trens subterrâneos, elevadores, automóveis, aviões etc., tem este mundo sensível os traços do trabalho consciente de si; não é mais possível distinguir entre o que pertence à natureza inconsciente e o que pertence à práxis social (HORKHEIMER, 1983b, p. 126).

Para Horkheimer, a aparência da teoria tradicional é a mesma da produzida pela lógica do capital, que promete a liberdade e a igualdade sem jamais realizá-las. Nesse sentido, dialeticamente, a parcialidade da teoria tradicional é também real, porque expressa a parcialidade de um tipo de sociedade. Por isso, eliminar o aspecto parcial da teoria tradicional, não significa negar a teoria tradicional sem mais. Antes, trata-se de conscientizá-la das causas de sua limitação, contextualizando seus resultados pelo papel dela na sociedade capitalista, de modo a integrá-la sob nova forma ao conjunto do conhecimento crítico. Entretanto, se é assim, a crítica não se limitaria ao conhecimento produzido no capitalismo, almejando, também, a própria realidade objeto desse conhecimento. No caso da economia política seria mostrar "a intensificação da injustiça social no conceito da troca justa, o domínio do monopólio no de economia livre, a consolidação de situações atravancadoras da produção no de trabalho produtivo, a pauperização dos povos no de sobrevivência da sociedade" (HORKHEIMER, 1983a, p. 157).

O procedimento de incorporar a teoria tradicional à teoria crítica vale também para a especialização das ciências humanas, que era crescente já na época de Horkheimer. Evitá-lo é arriscar a maior fragmentação do objeto de estudo (a sociedade) em perspectivas analíticas especializadas e segundo fundamentos que dificultam a compreensão da ordem existente em seu conjunto. Foi para encontrar um sentido afirmativo ao movimento de crescente especialização que Horkheimer lançou as bases de seu materialismo interdisciplinar, no qual pesquisadores de diferentes áreas do conhecimento teriam como horizonte comum a teoria de Marx.

Segundo Honneth (1999), nessa primeira fase da teoria crítica, a economia política, a psicologia e a crítica cultural se articulariam para a compreensão da fase pós-liberal do capitalismo, da integração psicossocial do indivíduo à sociedade e do funcionamento da cultura de massa. O importante é que, como as verdades da teoria crítica não podiam ser verificadas ou falseadas com referência à ordem presente, simplesmente porque estava em busca de uma ordem diferente, ainda que latente na atual, ela foi receptiva aos insights gerados pelas experiências pré-científicas, reconhecendo a validade da imaginação estética e da fantasia enquanto repositório de aspirações humanas genuínas (JAY, 1984).

Foi essa experiência interdisciplinar que permitiu a Horkheimer formular seu diagnóstico do seu tempo presente. Desde então, sob um regime de permanente renovação, acadêmicos e não acadêmicos vêm interpretando, dentro de suas áreas de interesse, uma imagem da sociedade capitalista em seu conjunto, simultaneamente organizada na valorização do capital, mas apresentando potenciais de superação em relação à dominação do mesmo. Vejamos como a apropriação desse projeto se deu na obra do ensaísta e cineasta Guy Debord. 


\section{Teoria Crítica da Sociedade do Espetáculo}

A expressão "teoria crítica" é comum a várias áreas do conhecimento. Na área da Administração, ela está presente em linhas de pesquisa, subáreas de estudo, grupos de discussão em alguns dos principais congressos no Brasil e fora dele. Teoria crítica, para que não haja mal-entendidos ao lermos Guy Debord, significa uma oposição radical ao objeto em foco. Como vimos na seção anterior, e de acordo com Adorno (2002), com os teóricos de Frankfurt, a teoria crítica se popularizou nos círculos acadêmicos e tornou-se um modo de expressão contra diversos setores da sociedade capitalista. Assim, temos a teoria crítica da arte por meio da crítica de uma indústria cultural, a teoria crítica do discurso (MAGALHÃES, 2004), a teoria crítica nas organizações (SOUZA, SALDANHA e ICHIKAWA, 2004; PAULA, 2007), entre outras (CORREIA, 1998). Desse modo, e tentando resumir o que não é impossível, a teoria crítica se pauta na negação (DEBORD, 1997) e toma forma como teoria crítica da sociedade.

Quando Guy Debord propõe uma teoria crítica da sociedade do espetáculo, em 1967, está propondo uma negação total da sociedade como ela se encontra. Ao produzir seu pensamento em negação, o autor pratica a oposição à lógica do que ele denominou "espetáculo". Se o espetáculo possui uma linguagem própria que não permite sua negação integral, para Guy Debord essa negação deveria ter sua própria linguagem (AQUINO, 2006). A partir desse entendimento, e em proximidade a Adorno (1998, p. 220), para quem "a arrogância contra a sociedade é uma arrogância contra a linguagem dessa sociedade", a proposta do autor é constituir uma linguagem da negação. Essa negação como teoria crítica se manifesta não apenas como negação teórica, mas como negação prática de toda submissão à sociedade do espetáculo. Se toda a vida está submetida às modernas condições de produção de espetáculos na sociedade (DEBORD, 1997), para Debord, é necessário que se negue toda a sociedade concebida por meio dessa situação comunicativa estabelecida pela linguagem espetacular (AQUINO, 2006).

Do movimento de negação do espetáculo, núcleo da teoria crítica do autor, surge a impossibilidade de flexibilização de seu pensamento. Até então, torna-se difícil conceber uma aplicação específica e/ou um entendimento parcial do espetáculo, pois não se entende uma linguagem a partir de "sublinguagens", mas a partir de seus elementos sintáticos/semânticos que conferem coerência e coesão, mesmo que por meio da expressão contraditória.

Quanto a isso, aparentemente, a linguagem da negação de Debord pode ter sido influenciada por outro teórico crítico, Walter Benjamin. Décadas antes, ao despir o método tradicional de seus fundamentos teológicos das leis de causa e efeito, esse autor comentou que "o eterno é, em todo caso, antes uma dobra na vestimenta do que uma ideia" (Benjamin, s.d., apud. ADORNO, 1998, p. 226). Para Jay (1996), a preferência de Benjamin por analogias a conceitos pode ter inspirado a teoria crítica, já que muito dos escritos do instituto, e os de Adorno em particular, caracteriza-se pela justaposição, às vezes deslumbrante, às vezes desconcertante, de afirmações altamente abstratas com observações aparentemente triviais.

Um dos principais méritos perceptíveis no pensamento de Debord é a noção de que todas as dimensões da sociedade participam do todo espetacular: a união do separado enquanto separado. Por isso, há o risco de desenvolver uma crítica aparente e separada sem considerar o todo, acreditando em certa autonomia com relação à economia política espetacular. Aquino (2006, p. 185, grifo nosso) vê no autor que:

A teoria [...] é tão finita e passageira quanto o são as gerações dos homens; produzida no tempo, diz respeito às lutas do tempo e, neste sentido, cumpre uma função estratégica. Assim, longe de um saber total, ele propõe uma crítica total às condições de existência da sociedade dominada pela mercadoria. Somente como crítica de totalidade a negação da atual forma histórica da sociedade pode ser de fato crítica e negativa, protegendo-se da recuperação própria a qualquer crítica "no varejo". 
Dessa forma, o autor francês não se prepara como um teórico, mas como um estrategista que pretende avançar na luta contra o "alfa e o ômega do espetáculo": a separação (DEBORD, 1997, p. 21). A escolha de Debord, então, é por uma teoria crítica total.

A ideia de espetáculo, tomando como base o teatro, pressupõe a separação. Seja a separação entre atores e público ou entre diretor/dramaturgo e os atores. Para entender a teoria crítica de Guy Debord é necessário lembrar que o espetáculo é uma metáfora e não a crítica superficial a quem assiste e a quem atua nele. É preciso compreender também que não se critica a dimensão do visível como aquilo que se vê em propagandas, anúncios, comerciais. Essa é apenas uma faceta superficial do espetáculo. Para Debord (1997, p. 14), "o espetáculo não pode ser compreendido como o abuso de um mundo da visão, o produto das técnicas de difusão maciça das imagens". Analogamente à concepção moderna de teoria, cujo exercício da ciência se vê separado da sociedade dividida em classes e produtora de mercadorias (NOBRE, 2004), a sociedade do espetáculo é composta por separações, várias delas, que acabam por se basear em algumas bem específicas. Essas separações fundamentais podem ser constatadas na Figura 1.

Figura 1

\section{A LINGUAGEM DO ESPETÁCULO: A SEPARAÇÃO}

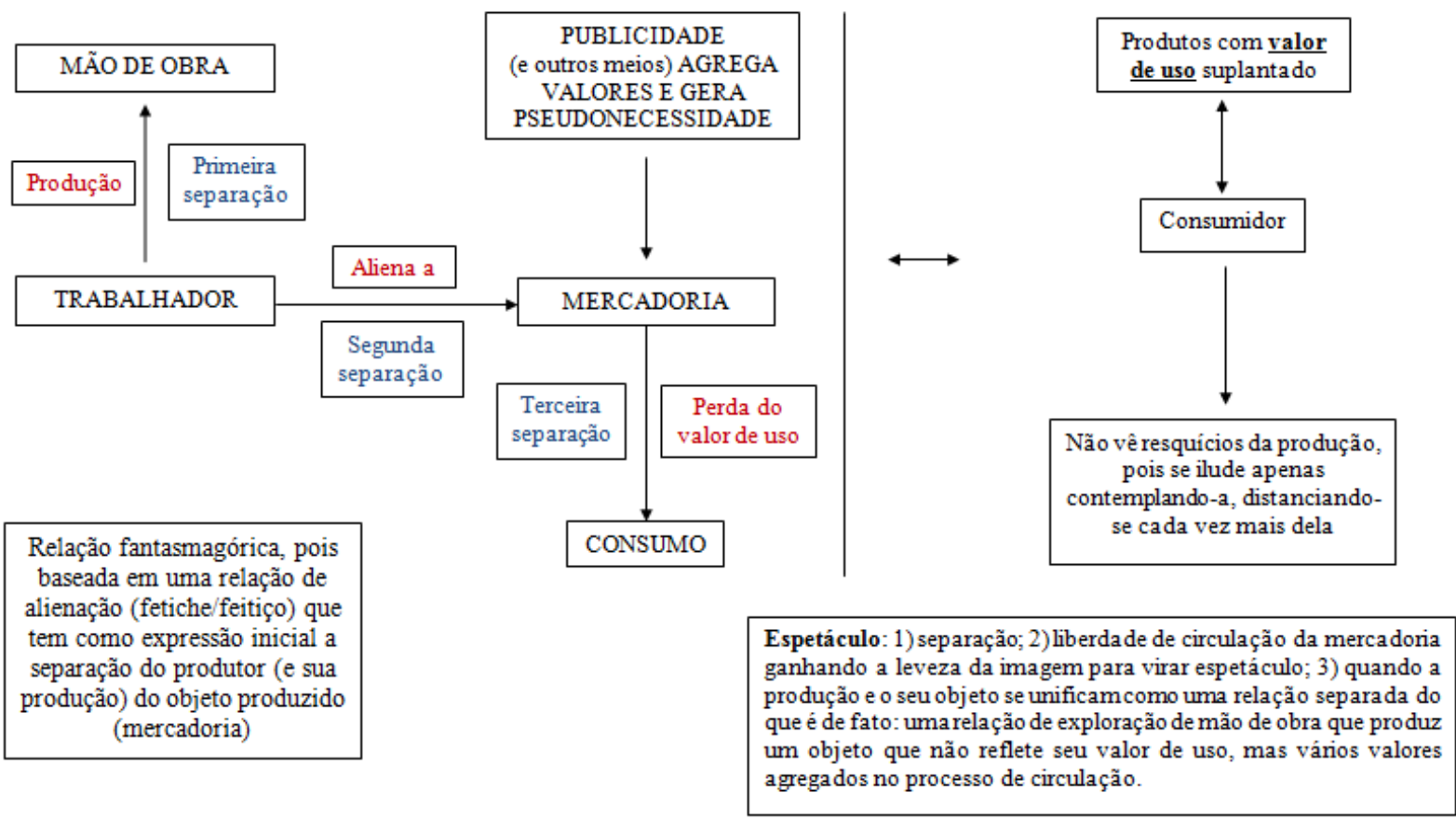

Fonte: Elaborada pelos autores.

As separações não se restringem às apontadas na Figura 1, mas se ampliam - com base na produção - para outras (Figura 2). 
Figura 2

\section{BUROCRACIA E HIERAROUIA NA LUTA POLÍTICA}

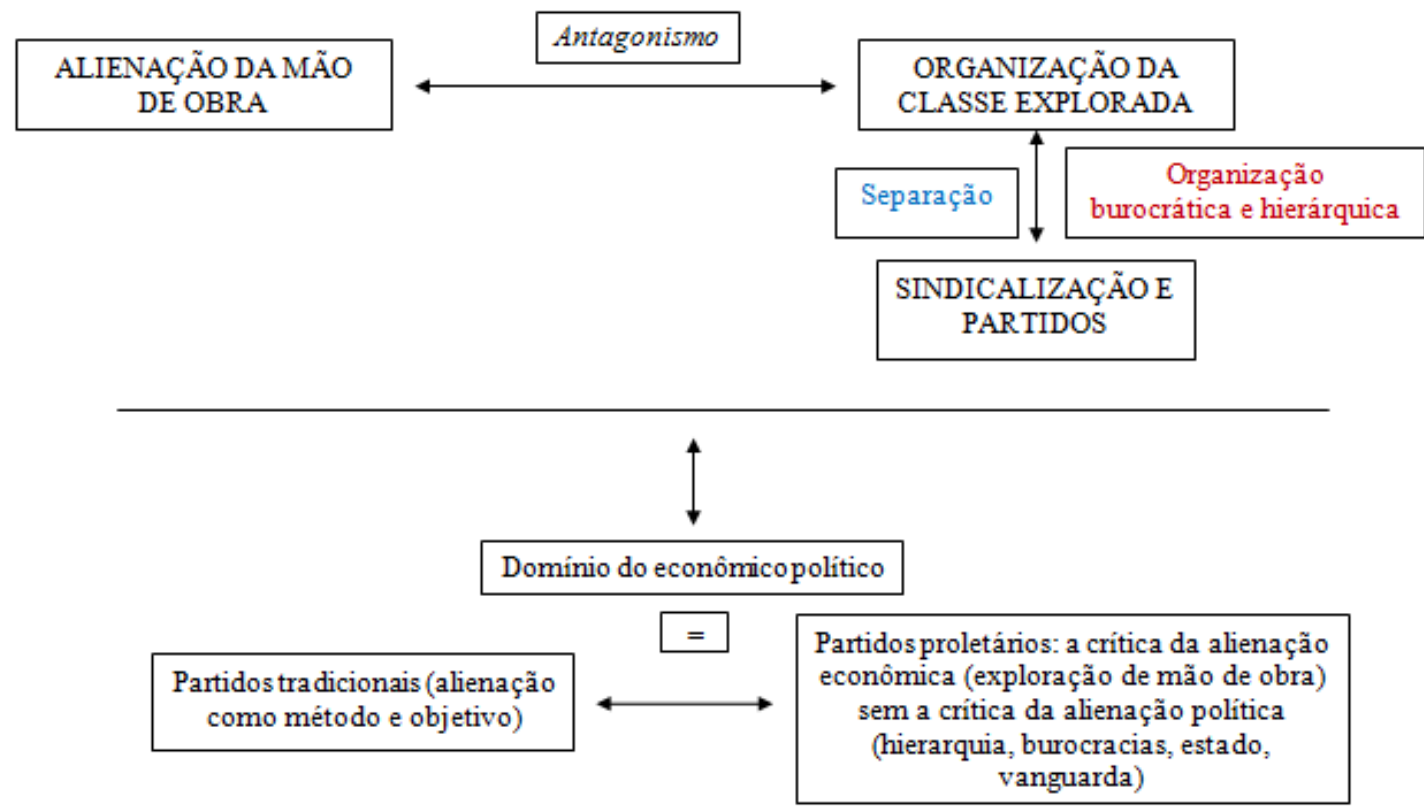

Fonte: Elaborada pelos autores.

O espetáculo se manifesta enquanto separação entre quem produz e quem detém os meios de produção, entre a força de trabalho e os instrumentos de trabalho. A mercadoria e seu produtor também estão distanciados. Como um potencial consumidor, o produtor também está separado do objeto de consumo. Essa "é a afirmação onipresente da escolha já feita na produção, e o consumo que decorre dessa escolha. Forma e conteúdo do espetáculo são, de modo idêntico, a justificativa total das condições e dos fins do sistema existente" (DEBORD, 1997, p. 14-15, grifo do autor) Assim, ao se submeter ao processo de alienação do trabalho, há uma cadeia de separações que se ramifica até o aspecto sensível da mercadoria, manifesta, muitas vezes (mas não unicamente) na publicidade. O movimento de separação é inerente ao processo produtivo, o processo espetacular já está na produção e não no consumo do aparente. Aquino explica que a noção de "aparência" em Guy Debord, vem de Karl Marx, que também é a principal referência da teoria crítica da década de 1930, e não da ideia de "ver" ou do "visível" no senso comum.

Para o autor,

[...] o conceito de aparência nesta crítica teórica não remete, em primeiro momento, à aparência sensorial-visível, mas antes às categorias, de origem hegeliana, de aparência (Schein) e aparição (Erscheinung), nas quais Marx situa as trocas de equivalentes nos primeiros capítulos de $\mathbf{O}$ Capital, que tratam da circulação de mercadorias e dinheiro. [...] De modo expresso, Marx concebe o caráter fetichista da forma-mercadoria determinado não pela "natureza física" dos produtos ou pelas "relações materiais" presentes no intercâmbio prático entre os indivíduos durante sua produção, mas, exclusivamente, pela forma social desse mesmo intercâmbio, enquanto intercâmbio mercantil; portanto, aquele não diz respeito à aparência sensível, mas sim à "aparência objetiva das determinações sociais do trabalho". É esta aparência objetiva do intercâmbio mercantil que se constitui 
numa objetividade fantasmagórica, pois se apresenta aos homens, em sua experiência prática, como uma relação natural, constitutiva das próprias coisas, embora seja uma determinação da forma histórica de suas relações sociais (AQUINO, 2007, p. 170, grifo do autor).

O espetáculo, portanto, é uma organização estética no mundo. A estética não mais submetida ao campo da arte e sua fruição, esfera esta que, para o autor, encontra-se entranhada na sociedade espetacular. Por esse motivo, ao analisar parcialmente um setor da sociedade, uma organização, a cultura, uma obra de arte, segundo o pensamento de Debord, é realizada uma análise insignificante, caso não se considere a relação imediata com a sociedade do espetáculo. Uma análise parcial da sociedade seria, então, uma crítica estética executada com a linguagem do próprio objeto, ou seja, com a linguagem do espetáculo, fazendo, de forma mágica e distante, parte do objeto criticado. Nisso, o autor nos faz lembrar Adorno que, sob a influência de Walter Benjamin, empreendeu desde cedo as primeiras tentativas de enriquecer a filosofia da história materialista com os métodos de interpretação estética (BUCK-MORSS, 1977). Devemos apenas lembrar que, para o situacionista, não tratamos mais da filosofia ou de um materialismo histórico.

Por hora, o que foi apresentado do pensamento de Guy Debord basta para darmos prosseguimento a este artigo. É necessário dizer que podemos aprofundar a análise do autor, inclusive, para expor incoerências, ou para compará-lo a outros autores críticos. Porém, como este estudo almeja introduzi-lo à área de Administração, verificando sua recepção, reservaremos para outro momento as possibilidades de imersão em sua teoria.

\section{Um Panorama da Recepção de Guy Debord}

\section{Uma recepção ainda recente}

Apesar de ser um autor muito lido em diversos círculos intelectuais, sua obra ainda não gerou uma recepção acadêmica densa. Tal fato também ocorreu aos autores críticos frankfurtianos cujas obras ("Eclipse da Razão", "Minima Moralia", "Dialética do Esclarecimento" etc.), nas primeiras décadas após ser publicadas, tiveram muito pouca repercussão (JAY, 1996). O motivo, possivelmente, é que a teoria do espetáculo também ataca a academia. Guy Debord criticou e fez piadas com os círculos universitários. A mais famosa é o fato de ele se considerar um "Doutor em nada" (DEBORD, 2002, p. 21) ao invés de um autodidata. Debord também desferiu ataques ao estruturalismo em algumas teses de seu livro (DEBORD, 1997), garantindo um distanciamento não apenas do estruturalismo em si, mas de outras correntes que dele derivam.

A ampliação de sua recepção em movimentos políticos ocorreu nas décadas finais do século XX, sobretudo na década de 1990, quando o capitalismo assumiu de vez sua forma global e, junto a ela, um movimento de contestação internacional se levantou. De modo resumido, as ações globais anticapitalistas foram ocupações periódicas das ruas em resposta aos encontros dos grandes bancos internacionais e encontros dos líderes dos países mais ricos, tais como o encontro da Organização Mundial do Comércio em Seattle, nos Estados Unidos, em 30 de novembro de 1999. Ao mesmo tempo que os manifestantes anticapitalistas tentavam atrapalhar o encontro, em várias cidades do mundo outros manifestantes paravam ruas, reuniam-se em praças e faziam passeatas anticapitalistas. Em alguns lugares, essas ações foram denominadas carnaval de lutas anticapitalistas. Esse nome não foi definido por acaso, pois da paisagem cinza das cidades de concreto emergiam pessoas pintadas e mascaradas que rabiscavam os muros, carregavam bonecos e faixas, batucavam contra o capitalismo e a falta de vida (RYOKI e ORTELLADO, 2004).

A forma de organização desse movimento é o que mais chama a atenção. Normalmente sem lideranças e com a organização a partir de coordenações e não de partidos e sindicatos, a adesão e simpatia das pessoas comuns foi muito grande. A inspiração não veio apenas dos situacionistas ou Guy Debord, mas toda uma 
geração que se articulou de modo diferente dos partidos e sindicatos do século XIX e foi incorporada no século XX. As expressões de rebeldia nas ruas do final do século XX e início do século XXI carregavam em si o desejo de uma nova forma de organização da vida que já praticavam. Essa forma guarda semelhanças com a formação de conselhos de trabalhadores. Para Guy Debord:

A constituição da classe proletária como sujeito é a organização das lutas revolucionárias e a organização da sociedade no momento revolucionário: é aí que devem existir as condições práticas da consciência, nas quais a teoria da práxis se confirma tornando-se teoria prática. Entretanto, esta questão central da organização foi a menos considerada pela teoria revolucionária na época [século XIX] em que se fundava o movimento operário, quando essa teoria ainda possuía o caráter unitário vindo do pensamento da história (e que ele se tinha dado como tarefa desenvolver até uma prática histórica unitária). A questão da organização é, ao contrário, o lugar da inconsequência dessa teoria, ao admitir o uso de métodos estatais e hierárquicos tirados da revolução burguesa. Em contrapartida, as formas de organização do movimento operário desenvolvidas com base nessa renúncia da teoria tenderam a impedir a permanência de uma teoria unitária, dissolvendo-a em diversos conhecimentos especializados e parcelares. (DEBORD, 1997, p.60-61, grifo nosso).

A nova forma de organização era, na verdade, a forma mais conhecida de organização da vida. O conselho, enquanto espaço prioritário de organização e decisão, comunicava-se diretamente com outros conselhos (PANNEKOEK, 1936; 1947). Também possui uma forma que se adéqua aos espaços e ambientes nos quais se constitui. Trata-se da forma social preferida por Debord, devido à sua condição especial de comunicação e criação de linguagem. Essa foi a forma preferida para as ações globais anticapitalistas, ainda que os locais de organização das ações fossem os mais diversos dentro da sociedade. Devido a essa forma de organização privilegiar a diversidade, os grupos de organização vertical e burocrática tiveram dificuldade para participar das preparações dos eventos, a menos que delas se apropriassem devido ao seu maior número.

Por servir como uma crítica prática ao capitalismo, o livro A sociedade do espetáculo, de 1967, foi lido desde as preparações para o maio de 1968 até os dias de hoje muito mais como um manual tático de crítica prática do que um livro de filosofia que pratica a crítica da economia política. A sociedade do espetáculo é um livro que não possui uma área específica, mas elabora sua crítica na oposição a conceitos de várias delas, talvez por isso alguns especialistas acreditem que Debord era um filósofo ou escritor erudito, artista ou historiador. O situacionista também viu a necessidade de apropriar-se das variadas tradições para constituir sua teoria crítica. Para ele,

A teoria crítica deve comunicar-se em sua própria linguagem, a linguagem da contradição, que deve ser dialética na forma como o é no conteúdo. É crítica da totalidade e crítica histórica. Não é um 'grau zero da escrita', mas sua inversão. Não é uma negação do estilo, mas o estilo da negação (DEBORD, 1997, p. 132, grifo do autor).

Mesmo sabendo do caráter prático da teoria de Debord, é possível encontrar estudos sobre sua obra na academia dentro e fora do Brasil. Essa recepção é muito variada e ocorre em maior número na área da comunicação sob os mais variados matizes. A leitura de Guy Debord tende a se voltar a uma aplicação ou ao estudo da situação de comunicação midiática. A tentativa de utilização do autor para analisar a mídia contemporânea é um esforço enfraquecido se não se consideram as condições do espetáculo de maneira geral. É o caso do livro de Naomi Klein, Sem logo, que também aponta a influência de Guy Debord e do "situacionismo" nos métodos de intervenção dos ativistas anticapitalismo/antiglobalização da virada do século, denominados culture jammers:

Mas embora os culture jammers utilizem liberalmente os movimentos de vanguarda do passado - do dada e do surrealismo ao conceitualismo e o situacionismo - o quadro que 
esses revolucionários da arte estavam atacando tendia a ser o mundo da arte e sua cultura passiva de espectadores, bem como o ethos antiprazer da sociedade capitalista dominante (KLEIN, 2002, p. 206, grifo do autor).

Quanto à citação acima, existe outro equívoco. É comum acrescentarmos um sufixo "ismo" quando falamos sobre uma vanguarda, um agrupamento ou um conjunto de ideias que inspira diversos outros indivíduos, teorias ou grupos. Aconteceu assim com as ideias de Karl Marx e os marxismos, com o surrealismo, com o leninismo etc. No caso da Internacional Situacionista não foi diferente. Todavia, é importante ressaltar que, para os situacionistas, não existe "situacionismo", pois isso contradiz de maneira muito inocente a própria crítica às ideologias da crítica social.

Há, também, a recuperação do autor que busca estudá-lo, ou até atualizá-lo, em sua crítica da sociedade contemporânea. Essa recepção passa, inicialmente, por autores e grupos que acabam por desenvolver um pensamento com base no que Debord oferecia de mais radical: a negação da sociedade do espetáculo. O espetáculo, como uma economia política estetizada passou a ser uma teoria bem recebida por autores como Giorgio Agamben (2002; 2007c), Mario Perniola (2007; 2009), Michael Hardt e Antonio Negri (2001; 2005), Paolo Virno (2003), Robert Kurz (1999) e Anselm Jappe (1999). Não é por acaso que esses autores e teóricos possuem relação com movimentos e ações anticapitalistas, bem como são ou foram professores em universidades da Europa e dos Estados Unidos.

Entre as recepções dos autores citados, Anselm Jappe é o mais dedicado a comentar a obra de Debord. Os outros autores o leram e, de certo modo, discutem a sociedade contemporânea com base em suas ideias buscando atualizá-lo, isto é, utilizam sua teoria crítica parcialmente.

No Brasil, a recepção de Guy Debord pela academia tem ocorrido de várias formas e encontra na tese de João Emiliano Fortaleza de Aquino (2005) um divisor de águas. Em sua tese, na área da filosofia, revela a relação entre André Breton e Guy Debord pelos conceitos de linguagem e de reificação. O autor também lançou um livro em 2006, focando a discussão sobre linguagem e reificação em Debord.

O livro de Aquino mostra como Guy Debord busca uma linguagem em que a questão estética e a crítica social encontram-se unidas. No livro, o autor mostra que o teórico francês desenvolve uma teoria crítica que procura suplantar a linguagem do espetáculo. Esse processo torna-se possível se houver a constituição de uma linguagem comum, uma linguagem que não se paute na submissão dos indivíduos ao processo de separação. O mérito do livro é revelar com clareza o caminho da reflexão (radical) de Debord, algo que ainda não havia sido alcançado pela recepção brasileira e mesmo do exterior.

Aquino (2003) historiciza a recepção do livro no Brasil na apresentação de uma edição pirata de $A$ sociedade do espetáculo:

A primeira edição de A sociedade do espetáculo só veio à luz no Brasil em julho de 1997, quase trinta anos após a primeira edição francesa e mais de duas décadas de sua tradução nas principais línguas do mundo. Em 1972, houve uma primeira edição em Portugal, que Debord considerou a única que, com certeza, tivera até então uma boa tradução logo na primeira tentativa.

O grupo ao qual Debord fazia parte, a Internacional Situacionista, já havia sido objeto de estudo de Olgaria Matos (1981), quando a autora pesquisou o Maio francês. Depois disso, vários outros intelectuais publicaram sobre Guy Debord no Brasil. Alguns conseguiram apresentar leituras menos instáveis sobre o autor (RIBEIRO, 1997; FREDERICO, 2010). Neles não se ignora a teoria crítica da sociedade. Essas leituras buscam coerência e estabilidade ao não tentar encaixar Guy Debord em uma linha de pensamento (i. e., marxismo) ou em um conjunto de tendências sobre uma época (i. e., pós-moderna). 
Como o propósito deste artigo não é apresentar um estudo das variadas leituras da obra de Guy Debord, basta afirmar que tal recepção compreende áreas como a arte, os estudos sobre o discurso e, como se viu, a comunicação, todas com diversos trabalhos que acabam conduzindo o autor ao lugar de crítico ou teórico de arte; um antiartista; um autor que tem a contribuir com as análises discursivas; ou alguém que criticou a mídia de massas.

Desde a década de 1990, não apenas no Brasil, mas no mundo, há um aumento da recepção da obra de Guy Debord. Alguns autores se incomodam com o caráter superficial com o qual a teoria é recebida. Esse é o caso de Robert Kurz (1999, p. 5), que afirmou:

Guy Debord e os outros situacionistas franceses estão na moda. É o pior que lhes poderia acontecer. Pois a moda é o oposto da crítica. Crítica radical não pode virar modismo sem perder a alma. O que está na crista da onda é a maneira como ideias são transformadas em lixo de praia. Na leitura pós-moderna em voga, a declaração de guerra situacionista à ordem dominante parece uma crítica aos meios de comunicação, tão ao gosto da própria mídia, no melhor estilo de um Neill Postman, ou uma manobra culturalista para esquerdistas "criativos" que gostam de surfar, aparentemente de modo radical, nas ondas da indústria da consciência. Mas Guy Debord não merece ser confundido com Baudrillard e ser reduzido ao formato de um pôster pop cultural.

A leitura rasa de Guy Debord e a consequente reprodução sem reflexão sobre sua teoria acabou gerando uma enorme quantidade de estudos sem sentido, como vemos na denúncia do autor acima.

Com a incorporação do acervo de Guy Debord à Biblioteca Nacional da França, desde o início de 2011 (LE MAGAZINE LITTÉRAIRE, 2011), acreditamos que vários estudos acadêmicos sobre o autor irão surgir, tendo em vista que o Ministério da Cultura francês o considerou um "tesouro nacional" (GALLIX, 2009). Apesar desses desfechos irônicos, tal qual a incorporação de um autor "arredio" ao Estado francês e, consequentemente, à cultura, é possível que surjam leituras importantes para compreender melhor o autor.

\section{A América Latina e A sociedade do espetáculo}

A respeito da recepção dos escritos situacionistas na América Latina, em 1970, Luis Camnitzer (2008) escreveu uma espécie de genealogia da história da arte, a qual caracterizava por meio de reflexões sobre "Dada - situacionismo - Tupamaros - conceitualismo". Décadas depois, o autor veio a descartar sua tentativa de construir uma história da arte por parecer totalizante e redutora. Ele concluiu, também, que ainda antes da primeira tradução para o espanhol do livro de Debord, que surgiu em 1973, em uma versão pirata de A sociedade do espetáculo pela Ediciones Flor, de Buenos Aires, já existiam movimentos latino-americanos que relacionavam arte e política, sem influência da teoria situacionista. Ou seja, no fundo, essa recepção dialoga com a influência do maio de 1968 francês em todo o mundo. Para Aquino (2003, p. 89, grifo do autor),

[...] os próprios situacionistas, em sua análise do maio francês, não deixaram de exagerar a influência do "movimento de ocupações" (de fábrica pelos operários grevistas) em maio sobre as lutas que se desenvolviam nos países semi-industrializados da América Latina. "A luta nos países capitalistas modernos", dizem eles em uma primeira publicação sua sobre o movimento de maio, "tem naturalmente relançado a agitação dos estudantes contra os regimes ditatoriais, e nos países sub-desenvolvidos. Ao fim de maio [de 68], houve violentos confrontos em Buenos Aires, em Dakar, em Madrid, e uma greve de estudantes do Peru. Em junho, os incidentes se estenderam ao Brasil; ao Uruguai — onde culminaram em uma greve geral; à Argentina; à Turquia, onde as universidades de Istambul e de Ankara 
fora ocupadas e fechadas sine die; e até ao Congo onde os secundaristas exigiram a supressão dos exames".

Nesse sentido, Camnitzer (2008) percebeu a dificuldade de pensar criticamente os movimentos, participantes do que ele denominou "conceitualismo", em sua complexidade e amplitude, quando não relacionados à corrente crítica francesa. Tal análise permitiu ao autor estabelecer divergências, semelhanças e influências mútuas entre as estratégias e as atitudes de ambos os movimentos. Por um lado, o ativismo situacionista nunca foi forçado à clandestinidade apesar de Debord considerar que foi perseguido em alguns momentos e, ainda, que seus textos sintetizem e elaborem ideias e ações de organizações e indivíduos comprometidos com atividades político-criativas (CAMNITZER, 2008). Por outro, tanto essas organizações e esses indivíduos como a Internacional Situacionista, se esforçavam ao seu modo para integrar a arte na política, mas não no sentido da polaridade estabelecida por Walter Benjamin, que associou a "esteticização da política" ao fascismo e "politização da arte" ao comunismo (BENJAMIN, 1994), mas, ao contrário, no sentido de minimizar a separação entre a arte e a vida e eleger as opções disponíveis contra o capitalismo e suas formas de exploração (CAMNITZER, 2008).

Tomemos três exemplos de táticas no conceitualismo dados pelo autor. Primeiro, a organização Tupamaros (Movimento de Libertação Nacional - Tupamaros), que, apesar de não ter a estética como preocupação central, buscava comunicar suas ideias "ilegais" diretamente ao público e, de forma "memorável", desfazer a imagem de que o Uruguai vivia uma suposta normalidade democrática. A revolução deveria acontecer antes de tudo na mente das pessoas, e, como escreveu Debord (1957): "Aquilo que muda o nosso modo de ver as ruas é mais importante que o que muda o nosso jeito de ver a pintura". Segundo, o artista plástico Cildo Meirelles que, no Brasil dos anos 1970 e 80, apropriava-se de dinheiro e de garrafas de Coca-Cola, alterava suas mensagens com conteúdos ideológicos e reintroduzia-os nos circuitos normais de circulação, estimulando que as pessoas escrevessem seus próprios comentários. Citando o détournement situacionista sem sê-lo - ele teve a intenção de utilizar para seus próprios fins, os mesmos processos de consumo que alienavam as pessoas. Por fim, no México, o "Superbarrio", um ativismo coletivo de bairros de periferia cuja estética remete às cenas de luta livre, à cultura de lenda urbana, ao teatro de rua e ao circo mexicano. Ainda que não se saiba quantos sejam os organizadores e participantes desse movimento, o "Superbarrio" se converteu em um personagem que utilizou das capacidades "sobre-humanas" do espetáculo para solucionar crises locais (evitar que inquilinos pobres fossem desalojados etc.) e fortalecer a comunidade dos bairros onde ele aparecia.

Esses exemplos ilustram o fato de que, situado às margens o conceitualismo formulou um programa poético/político que, durante as décadas de 1970 e 80, contrapunha-se àquela realidade opressora. Seu programa, próximo a um regime de micropolítica, instrumentalizou táticas e permitiu o tráfico de sentidos pelas bordas e os interstícios do status quo ditatorial. Busca-se, com esses exemplos, aproximar essas ações daquelas da Internacional Situacionista, algo não tão próximo como parece. Esse distanciamento aparece no trecho abaixo, apontando como as noções de "linguagem" e "poesia" fogem do campo da estetização da vida, tal como se viu na teoria crítica do espetáculo:

O poder vive de bens roubados. Não cria nada; recupera. Se criasse o significado das palavras, não haveria poesia, senão somente informação útil. A oposição não poderia expressar-se pela linguagem; qualquer rejeição estaria fora dela, puramente letrista. O que é poesia senão o momento revolucionário da linguagem, inseparável como tal dos momentos revolucionários da história e da história da vida pessoal? [...] Realizar poesia significa nada menos que criar, simultânea e inseparavelmente, eventos e sua linguagem (INTERNACIONAL SITUACIONISTA, 1967).

Por outro lado, é bom lembrar que Debord (1997) foi claro quando expressou, na tese 57 de seu livro, que não há só a hegemonia econômica, mas, também, uma hegemonia do espetáculo, que define a dominação das 
regiões subdesenvolvidas. Vimos, nos exemplos, como o "Superbarrio" mexicano, que o espetáculo na periferia cria seus próprios anticorpos e, posteriormente, novos corpos, em especial quando consciente de sua própria localidade. Poderíamos pensar se esse não seria o caso da contribuição, ainda que de forma dúbia, do conceito de "espetáculo" aos estudos sobre urbanismo e arquitetura no debate e reflexão sobre as possibilidades de práticas organizativas mais inclusivas no cotidiano das cidades latino-americanas (SCOCUGLIA, 2013). Dito isso, perguntamos: como estariam sendo criados esses anticorpos e novos corpos nos estudos organizacionais?

\section{Guy Debord na Administração}

Após uma pesquisa de estudos a partir de palavras-chave, percebemos que não são muitos os trabalhos da área de Administração que tratam de Guy Debord ou da sociedade do espetáculo. Mapeando a presença do autor, fizemos a busca de artigos em periódicos (Revista de Administração Contemporânea, Brazilian Administration Review, O \& S, Cadernos EBAPE.BR, RAE, RAC Eletrônica) e eventos (Encontro Nacional da Associação Nacional de Pós-Graduação e Pesquisa em Administração, Encontro Nacional de Estudos Organizacionais) da Associação Nacional de Pós-Graduação e Pesquisa em Administração (Anpad). O Encontro Nacional da Associação Nacional de Pós-Graduação e Pesquisa em Administração (EnANPAD) foi pesquisado entre 1997 e 2010, o Encontro Nacional de Estudos Organizacionais (EnEO) entre 2000 e 2010, as revistas foram pesquisadas entre janeiro de 1997 e dezembro de 2007. A busca no indexador Spell.org foi realizada com base em artigos que contivessem as palavras: Debord; espetáculo; espetacularização; espetaculares. Talvez essa busca não atingisse todos os artigos que apontam o autor nas referências bibliográficas, mas preferimos enfocar estudos nos quais a ideia de espetáculo aparecesse com destaque, preferencialmente no título.

Dessa busca, foram identificados apenas 6 artigos, todos oriundos de eventos, sendo 2 do EnEO e 4 do EnANPAD; 2 artigos utilizaram a palavra espetáculo como forma de apontar seu objeto, sem ter qualquer ligação com Guy Debord ou sua teoria.

Os artigos, ou os seus autores, não serão ocultados, uma vez que, ao expor o método de mapeamento, permitimos que qualquer dos leitores possa realizar a mesma busca e revelar a autoria. Apesar de essa discussão derivar de uma pesquisa de artigos que analisaremos, não se trata de um corpus para análise científica. Preferimos tratar como amostragem das leituras sobre o autor, bem como seu uso nos estudos da área da Administração.

A leitura sobre Guy Debord apresentada nos artigos representa aquele caminho instável apontado no início deste artigo. $\mathrm{O}$ interesse dos autores era constituir uma crítica ao objeto em questão e, para atingir seu objetivo, conduzem a teoria para esse objeto, muitas vezes não se importando, muitas vezes, se o que ele atribui ao teórico citado é o que realmente se disse.

Dos 6 estudos, 4 citam Guy Debord: "Metáforas espetaculares: do dramatismo teatral ao dramatismo cinematográfico", de Thomaz Wood Jr. (EnANPAD, 2000); "Reality shows e jogos (hiper) reais do espetáculo organizacional", de Marcos Goulart Castelo e José Luiz Felício dos Santos de Carvalho (EnEO, 2004); "O espetáculo como estratégia do marketing político", de Edna Aparecida Lisboa Soares (EnANPAD, 2008); e "Ideologia e espetacularização nas práticas discursivas gerenciais em uma loja de departamentos", de Francis Kanashiro Meneghetti e Édna Cicmanec (EnANPAD, 2010). Serão esses trabalhos que discutiremos a partir da próxima subseção. 


\section{Metáforas versus espetáculos}

Em seu texto, Wood Jr. (2000) estuda as metáforas. A partir disso, na abordagem do simbolismo organizacional, reflete sobre as metáforas da dramaturgia. O autor deseja entender como as metáforas possibilitam a análise do objeto, no caso, a organização. Metáforas são produtoras de analogias, e Wood Jr. (2000) percebeu que a teoria crítica de Debord trazia uma metáfora como conceito principal. O problema foi que, ao interpretar a teoria crítica do espetáculo pela metáfora, a crítica de Guy Debord foi limitada a um aspecto: a representação, melhor dizendo, a simbologia que se extrai da relação entre ator/espectador. Para Guy Debord, a metáfora do "espetáculo" é uma palavra que significa separação, a simbologia que se depreende da metáfora tem valor se submetida ao entendimento da separação generalizada na sociedade nos vários espetáculos. Para evitar a simplificação de sua teoria pela questão da simbologia, o autor mostra que "como indispensável adorno dos objetos produzidos agora, como demonstração geral da racionalidade do sistema, e como setor econômico avançado que molda diretamente uma multidão crescente de imagensobjetos, o espetáculo é a principal produção da sociedade atual” (DEBORD, 1997, p. 17, grifo do autor).

O artigo (WOOD JR., 2000) realiza um longo estudo da metáfora e sua história de aplicação intelectual. É provável que, pelo uso da metáfora teatral sobre a qual se debruçava, o autor acreditou ser justo incluir Guy Debord nesse percurso, pois a ideia de espetáculo no autor francês é, realmente, uma metáfora. A utilização metafórica em Debord, sem o estudo concreto de seu propósito, tal como afirmado acima, acaba por levar o leitor ao engano. Guy Debord não pretende desvelar, utilizando apenas a metáfora do espetáculo, a sociedade, mas a própria sociedade já está revelada no segredo que a compõe (DEBORD, 1997).

Para Wood Jr. (2000), "Enquanto Boorstin (1962) registra tendências relacionadas à prevalência da imagem sobre a substância, Debord (1994 [1967]) formula teoria sobre a construção de uma sociedade baseada na imagem". Na verdade, Guy Debord não pensa uma sociedade baseada na imagem, mas uma sociedade produtora de espetáculos, que são imagens. Espetáculos, como já foi afirmado, são separações que se manifestam como aparências. Para o autor francês, "o espetáculo é o capital em tal grau de acumulação que se torna imagem" (DEBORD, 1997, p. 25, grifo do autor), esse tornar imagem reside em seu processo de produção e acumulação e não na reprodução entre as imagens.

Outra questão colocada pelo autor (WOOD JR., 2000, p. 7, grifo do autor) é que Debord "mostra-se francamente pessimista quanto aos rumos do que denomina sociedade do espetáculo". Há, de fato, uma recepção de Guy Debord que o considera apocalíptico ${ }^{4}$ e/ou pessimista. Mesmo assim, não se prova que o autor francês é uma ou outra coisa, a não ser que por "pessimista" se entenda a negação e por "apocalíptico" se entenda a superação da sociedade espetacular. Dessa forma, Debord nega a sociedade do espetáculo com a esperança de construção de uma linguagem comum, uma nova comunicação que não seja a comunicação da sociedade do espetáculo.

Outra recepção equivocada da teoria do espetáculo que aparece nesse artigo é:

A espetacularização é uma consequência e um objetivo da modernização das condições de produção, que quebra a unidade de vida, estirpando-lhe [sic] as imagens e agrupando-as em uma grande e única corrente. Cria-se um mundo à parte, onde a relação entre as pessoas é mediada por imagens. Tudo o que era diretamente experimentado torna-se representação.

\footnotetext{
4 "Apocalíptico" é a contraposição de "integrado" - ambos "conceitos-fetiche", evasivos e polêmicos, criados por Umberto Eco nos anos 1970 para marcar as discussões sobre a cultura de massa. A polarização serviu para designar ao extremo as análises que se faziam à época: os que viam a cultura de massa como uma contraposição à cultura no sentido aristocrático - sendo, portanto, um sinal de decadência; e os que viam na cultura de massa o aumento da circulação de uma arte e de uma cultura popular consumidas por todos os grupos sociais. O "apocalíptico" consolava o leitor por estar acima da massa, sem dela fazer parte; já o "integrado" convidava o leitor para o desfrute dos produtos da cultura de massa (ECO, 1993). É importante reforçar que a crítica de Guy Debord não evoca a questão da cultura de massa, tal como faziam os autores da Escola de Frankfurt.
} 
O espetáculo cria uma auto-representação do mundo que é superior ao próprio mundo real. Ele funciona como uma ponte entre esses dois mundos, conservando-lhes o isolamento (WOOD JR., 2000, grifo do autor).

O exame da sociedade levado a cabo por Debord não revela a existência de mais de um mundo. As imagens não estão formando um mundo à parte $\mathrm{e}$, consequentemente, autorreferenciando-se. As imagens estão sendo produzidas e consumidas nesse mundo, nessa sociedade do espetáculo. É comum a muitos autores realizarem a leitura de Guy Debord por essa via devido à maior difusão de Jean Baudrillard na academia, para quem a imagem na sociedade contemporânea, uma sociedade do consumo, tem o poder de autorreferenciar-se, autorreproduzir-se. Anselm Jappe (1997, p. 4) aponta os problemas dessa recepção:

Para Debord [...] a imagem não obedece a uma lógica própria, como pensam, ao contrário, os pós-modernos "a la Baudrillard", que saquearam amplamente Debord. A imagem é uma abstração do real, e o seu predomínio, isto é, o espetáculo, significa um "tornar-se abstrato" do mundo. A abstração generalizada, porém, é uma consequência da sociedade capitalista da mercadoria, da qual o espetáculo é a forma mais desenvolvida. A mercadoria se baseia no valor de troca, em que todas as qualidades concretas do objeto são anuladas em favor da quantidade abstrata de dinheiro que este representa. No espetáculo, a economia, de meio que era, transformou-se em fim, a que os homens submetem-se totalmente, e a alienação social alcançou o seu ápice: o espetáculo é uma verdadeira religião terrena e material, em que o homem se crê governado por algo que, na realidade, ele próprio criou.

No artigo, a citação de trechos do livro de Debord mostra que a tradução do texto lido está correta, mas a leitura depreendida dali é influenciada pela perspectiva do consumo, da publicidade, propaganda, enfim, da recepção realizada pela área que mais publicou sobre $A$ sociedade do espetáculo, a comunicação, privilegiando o debate sobre a sociedade midiática. Não podemos negar a dimensão da crítica da mídia, como já afirmado anteriormente, mas essa é apenas parte da crítica, talvez seja a parte mais fácil para o leitor entender, porém, esse entendimento tem sido parcial e, mais ainda, superficial.

Nesse artigo (WOOD JR., 2000), pensa-se o espetáculo como sociedade midiática, ao tempo em que o autor tenta justificar a metáfora cinematográfica para a sociedade e suas organizações. Como vimos até aqui, pouco do que foi desenvolvido no artigo coaduna com as propostas de Guy Debord.

\section{Empresas e reality shows versus espetáculos}

Castelo e Carvalho (2004) desenvolvem um artigo sobre o que denominam "espetáculo organizacional". Com base nisso, comparam as empresas com os reality shows, por ambos terem pessoas desejando o sucesso, o status, fazendo intrigas etc. Os autores comparam a ideia de "espetáculo televisivo" a "espetáculo na empresa", permitindo que o leitor entenda que as disputas entre os empregados das empresas são espetáculos assistidos pela organização. A visão dos autores centra-se na questão do comportamento no reality show e na empresa como similares ou próximos.

É importante ressaltar que, aqui, não se avalia a lógica desenvolvida no artigo. Poderíamos até concordar que, dentro do modelo construído no texto, é possível relacionar os realities shows às empresas. Porém, o raciocínio levado a cabo, sob a unificação da teoria crítica de Guy Debord com outros teóricos, não se mostra coerente. Apesar de sua proposta clara, um artigo que cita Guy Debord corroborando ou em confluência com Jean Baudrillard merece alguns apontamentos.

Os autores afirmam que: 
A hiperrealidade é uma versão sanitizada da realidade, higienizada dos problemas mundanos, da sujeira, da violência, da exploração e das demais dificuldades impostas pelo cotidiano (BELK, 1996). A partir do momento em que não existe uma insistência para se enfatizar aquilo que é real, não se pode falar da verdade, somente de uma representação, a qual pode ser extrapolada para a realidade. Trata-se da construção de uma nova verdade a partir de uma hiperrealidade (SMITH, 2002), por meio da qual tende-se a privilegiar a fantasia, a estilização e o espetáculo (Debord, 1995), em acordo com a concepção de que as sociedades atuais não passam de produções cinemáticas e dramatúrgicas (PELZER, 2002; WOOD Jr., 2000) (CASTELO e CARVALHO, 2004, p. 4).

Nesse trecho, desconsidera-se que Guy Debord não se aproxima da visão da sociedade como uma "hiperrealidade", pois, para ele, a imagem não se autorreferencia, tornando-se possível sua automultiplicação. A imagem, na visão sobre o espetáculo de Debord, está relacionada com as várias separações que ocorrem na sociedade. Esse processo de separação generalizada não confere autonomia à imagem a ponto de haver autorreprodução no sentido de simulacro, mas a ponto de ser a manifestação imagética da separação, sua consumação que, inclusive, pode ser consumida como mercadoria. É dessa forma que a vida se banaliza e não devido ao processo de sua simulação.

Perniola (2007, p. 2) distancia Guy Debord de Jean Baudrillard do seguinte modo:

A análise de Baudrillard vai, pois, em uma direção totalmente diferente à que tomava Guy Debord: o mundo atual não estaria caracterizado pelo triunfo do espetáculo, mas por sua desaparição: a cena se substitui pelo obsceno, o lugar da ilusão é ocupado por algo que pretende proporcionar um efeito de realidade maior que a experiência da realidade (e é por isso hiperreal), cada evento resulta antecipado e anulado pela publicidade, pelas enquetes, pelas antecipações que impedem que seja sentido como tal.

Em Debord, o espetáculo se fortalece enquanto movimento de separação. Para Jean Baudrillard, há o desaparecimento do referente do signo, este passando a se tornar autônomo. Desse modo,

[...] a substituição do trabalho humano pela máquina teria posto fim à economia política como ciência. A produção, libertando-se do homem e de qualquer finalidade, passou a girar em torno de si mesma, tornou-se autônoma. Com o desaparecimento do trabalho humano, evapora-se o referente da economia - o valor, o tempo de trabalho como medida que regula o intercâmbio, a troca de mercadorias. Na linguagem, ocorre o mesmo movimento: o referente também se desvanece, possibilitando a emancipação do signo (FREDERICO, 2010, p. 187).

Essa perspectiva não existe em Debord, pois, para ele, a emancipação existe apenas no movimento de "aparecer".

A análise da dimensão midiática do espetáculo é a mais comum entre todos aqueles que desejam utilizar a teoria crítica de Debord, porém, o risco é tornar a análise superficial, pois isola a mídia das outras separações que ocorrem no espetáculo e acaba por inviabilizar uma crítica de fato negativa. Ao escolher essa leitura, os autores do estudo (CASTELO e CARVALHO, 2004) poderiam ter informado ao leitor que Guy Debord concebia a crítica ao espetáculo em sua totalidade e não acreditava no domínio do espetáculo como mídia (no caso, a mídia televisiva). 


\section{Marketing político versus espetáculos}

Soares (2008) analisa o que denomina "espetáculo político" no sentido do "marketing político". Apesar de reivindicar o conceito de espetáculo de Debord, o artigo cita-o apenas uma vez, a tese 4 (DEBORD, 1997), para mostrar que o autor acredita no espetáculo como uma produção da relação entre as pessoas, uma relação social. Isso justificaria, no texto, a discussão sobre o marketing político, uma vez que política, grosso modo, é relação.

Mesmo se essa tese fosse recebida pela autora como Debord a coloca, estaríamos incorrendo nos mesmos enganos de entender a crítica ao espetáculo como uma crítica às mídias, ou aos políticos, fazendo uso da mídia, o que não corrobora as propostas do teórico. Além de ser uma análise parcial do espetáculo, tal como indicado, Soares (2008) parte do pressuposto de que o espetáculo encontra-se apenas no âmbito da comunicação humana.

Para Guy Debord, como vemos em Aquino (2005; 2006), a dimensão comunicativa do espetáculo é unitária, total. O espetáculo possui uma linguagem apenas, que submete todas as outras expressões à sua lógica. Ao fazê-lo, constitui sua forma de comunicação, que é separada. Não considerar essa perspectiva em Debord é o mesmo que ignorar o núcleo central de sua teoria crítica, a negação do espetáculo, a busca por uma linguagem comum, uma linguagem não espetacular. A análise do discurso político expresso pelo marketing só pode ser realizada pedindo as licenças ao leitor para que se desenvolva o texto via conceito de espetáculo pelo senso comum.

\section{Ideologia em loja de departamentos versus ideologia no espetáculo}

Meneghetti e Cicmanec (2010) também buscam a aplicação da crítica de Guy Debord a um contexto parcial do espetáculo: uma loja de departamentos. Ao adotar essa proposta, os autores enfocam as práticas discursivas gerenciais e optam por fazer uma análise que considere a ideologia e o conceito de espetáculo (mais especificamente "espetacularização").

Para os autores, Guy Debord "afirma que o espetáculo é o espaço mestre para a atuação das organizações sobre os indivíduos, considerado o âmago do irrealismo da sociedade real, cuja forma e conteúdo consistem identicamente nas justificativas totais das condições e dos fins do sistema operante" (MENEGHETTI e CICMANEC, 2010).

No teórico francês, não conseguimos ver a dominação das organizações sobre os indivíduos como se referem os autores. Guy Debord, além de pensar no processo de alienação e fetiche da mercadoria, está preocupado com as formas de superar essas condições. Para ele, essas condições são fruto da dominação de uma classe sobre a outra, o que se resolverá apenas com o acirramento das lutas de classe (DEBORD, 1997).

Debord, aqui, concorda com Karl Marx, para quem o caráter de fetiche da mercadoria decorre do fato de seu caráter de coisa encobrir as relações sociais que a produzem de fato, ou seja, as relações de exploração do trabalho pelo capital. Em consequência, a mercadoria torna algo mágico e sobrenatural: um objeto inanimado com vida própria, alheia ao homem, sem o controle de seus produtores e consumidores. Um objeto cuja idolatria de seu aspecto de coisa oculta as relações de exploração, mas cuja posse confere ao seu possuidor um caráter especial. O próprio Marx (2003, p. 96) explica esse fenômeno:

O valor não traz escrito na fronte o que ele é. Longe disso, o valor transforma cada produto do trabalho num hieróglifo social. Mais tarde, os homens procuram decifrar o significado do hieróglifo social, descobrir o segredo de sua própria criação social, pois a conversão dos objetos úteis em valores é, como a linguagem, um produto social dos homens. 
Apesar dos objetivos de Guy Debord ao escrever A sociedade do espetáculo em teses fosse possibilitar ao leitor se municiar de cada uma, em momento propício, contra o espetáculo, muitas vezes, quando retiradas de seu contexto e aplicadas em outro há o risco de gerar contradição. Mesmo essas contradições eram esperadas pelo autor, que entende a teoria crítica que elabora como um estilo dialético e, portanto, contraditório. Porém, ao ler as teses no contexto, não necessariamente do livro, mas da teoria crítica do espetáculo, é difícil conceber a subversão de uma tese tal como esta:

As imagens que se destacaram de cada aspecto da vida fundem-se num fluxo comum, no qual a unidade dessa mesma vida já não pode ser restabelecida. A realidade considerada parcialmente apresenta-se em sua própria unidade geral como um pseudomundo à parte, objeto de mera contemplação. A especialização das imagens do mundo se realiza no mundo da imagem autonomizada, no qual o mentiroso mentiu para si mesmo. O espetáculo em geral, como inversão concreta da vida, é o movimento autônomo do não vivo (DEBORD, 1997, p. 13, grifo do autor).

Meneghetti e Cicmanec (2010), ao ler a passagem acima apenas a parafrasearam, trazendo-a ao seu texto como se Guy Debord acreditasse que a sociedade do espetáculo fosse um mundo "outro", um "pseudomundo" o qual está completamente livre, distante das possibilidades de emancipação humana. Porém, o "pseudomundo" é o mundo da separação que reproduz mais separações - ou espetáculos -, espetáculos estes que são acumulados em tal grau que se tornam imagens. A acumulação das separações - ou espetáculos - não as liberaram do sentido de realidade, apenas criaram um regime de falsidade, este, sim, promotor do irreal.

Na primeira edição brasileira, aquela usada pelos autores, basta virar a página para que a questão se esclareça na tese subsequente:

O espetáculo apresenta-se ao mesmo tempo como a própria sociedade, como uma parte da sociedade, e como instrumento de unificação. Como parte da sociedade, ele é expressamente o setor que concentra todo olhar e toda consciência. Pelo fato de esse setor estar separado, ele é o lugar do olhar iludido e da falsa consciência; a unificação que realiza é tão somente a linguagem oficial da separação generalizada (DEBORD, 1997, p. 14 , grifo do autor).

Com essa tese, vemos que não há entendimento de um mundo livre da possibilidade de negação, mas há uma autonomia da linguagem que só pode ser oposta com outra linguagem e não com sublinguagens suas. Ora, se no espetáculo seus meios são seus fins, ou seja, o espetáculo produz e circula espetáculos (DEBORD 1997), e espetáculos são relações sociais mediadas por imagens (DEBORD, 1997), não há como pensarmos uma "desmaterialização" dessa realidade a ponto de entendê-la como mundo sem referência. Por esse motivo, a ideologia, no espetáculo, só pode ser vista como algo do espetáculo, como todo o espetáculo, o que distancia Debord das concepções de Althusser (2001) e outros autores marxistas.

O tema ideologia é extremamente difícil de ser desenvolvido a partir de Guy Debord, talvez por isso, os autores (MENEGHETTI e CICMANEC, 2010) o trouxeram via Althusser (2001). No contexto das lutas proletárias ou no cotidiano, a ideologia é mais uma forma de separação. No autor francês, vemos que a ideologia é necessária em uma sociedade da separação, pois a "cura" ideológica move as pessoas para um entendimento de que nada está separado ou o que está separado (como o produtor que não detém os meios de produção) pode ser unido por meio da ideologia (de um partido, por exemplo). Os autores (MENEGHETTI e CICMANEC, 2010) acabam por não explicitar esse conceito fundamental (e de discussão extensa) no pensamento do intelectual francês. Talvez isso não tenha sido realizado porque o estudo dos discursos a partir da noção de ideologia de Guy Debord revela que todo discurso, gerencial ou não, que não se faça como negação total à sociedade do espetáculo é um discurso espetacular per se. 
É importante ressaltar que a questão da ideologia é um dos pontos do pensamento de Guy Debord sobre os quais os críticos centram suas problematizações justamente pelo caráter autônomo conferido a ela. Esse é o caso de Régis Debray (2003, p. 108, grifo do autor), para quem:

O erro [...] estava no ponto de partida. Debord e seus amigos tomaram para si a definição marxista da ideologia como reflexo invertido do real no fundo da consciência em câmera oscura. Eis porque logo se poderá recolocar o mundo, que segue com a cabeça em baixo, sobre seus pés. Como se em última instância fosse apenas uma falsa imagem que nos rouba o ser, bastará corrigir "essa consciência deformada das realidades", virar o espelho para o lado direito, isto é, o espetacular integrado (fusão do "espetacular concentrado" e do "espetacular difuso", no que se resumem o comunismo e o capitalismo), para reapossarmonos de nosso ser perdido. O projeto midiológico nasceu justamente da ruptura com aquela concepção espetacular da ideologia ou do "espetáculo". A ideologia não é a antítese de um saber ou de uma realidade, como ilusão, desconhecimento ou falsa consciência, mas sim a forma e o meio de uma organização coletiva.

Apesar dos problemas na concepção da teoria crítica de Debord como uma teoria "midiológica", a crítica do autor revela um dos maiores entraves da crítica ao espetáculo. Normalmente, há uma resistência ao entendimento da ideologia como "autonomizada". Desse modo, os críticos do teórico francês tendem a conceber sua crítica como negadora até mesmo da subjetividade humana no espetáculo - uma falsa acusação também atribuída a Adorno e Horkheimer, teóricos críticos que, provavelmente, também foram lidos por Debord e que pareceram não dar limites às formas de controle na sociedade do capitalismo tardio (COOK, 1996). Na verdade, o autor está fazendo uma previsão de que sua teoria também pode tornar-se uma ideologia separada, uma ideologia da anti-ideologia, por exemplo, bem como antevia as possibilidades de sua teoria crítica ser absorvida pelos meios acadêmicos e utilizada como uma teoria aplicada, integral ou parcialmente, tal como apontamos neste artigo.

Para que a diferença entre Guy Debord e os marxistas fique mais clara, é necessário que se faça um estudo detido sobre a matéria. A despeito dessa necessidade, este artigo não o fará por acreditarmos que o apontado até aqui já demonstra, em grande parte, os problemas da recepção do autor na área da Administração.

\section{Guy Debord e os Estudos Organizacionais}

Há uma enorme dificuldade para pensar a organização a partir de autores críticos da economia política. Essa dificuldade talvez se deva a uma necessidade da área de aplicar o pensamento, realizar estudo empírico etc. Ou então, talvez, não haja desculpa alguma, pois uma leitura do que o autor diz já prova a impossibilidade de sua utilização, a não ser como negação.

Mesmo assim, existem alguns temas que são comuns aos estudos organizacionais e ao pensamento de Guy Debord. Esses temas são passíveis de discussão a partir de Debord, desde que se tenha o cuidado de realizar uma leitura "estável" da teoria crítica do autor. Alguns dos temas que podemos elencar são: Administração e arte; Administração e cultura; Organizações burocráticas políticas; Organizações e movimentos sociais; Teoria Crítica das organizações; Administração e linguagem.

A relação entre os estudos organizacionais e a arte pode ser balizada pela crítica ao espetáculo que, com Guy Debord, é compreendida como mercadoria na relação entre produção, circulação e consumo. Contudo, essa concepção não é o final das possibilidades da arte hoje. A arte se dissolve como mercadoria se não é entendida nas lutas sociais contemporâneas. Os métodos artísticos, desde o século XX, passaram a ser incorporados não como arte, mas como práticas de subversão. Vide, por exemplo, as pixações (sic). Enquanto expressões da resistência emergem no dia a dia e não são frutos do campo artístico, apesar de que, 
há algum tempo, o campo da arte deseja absorvê-la por inteiro relegando ao esquecimento sua parte mais radical.

A Administração e a cultura tem sido uma das relações mais estudadas. Ao pensarmos que a cultura está submetida ao espetáculo, o entendimento dela como parte de organizações e em suas correlações pode partir do teórico francês. Com Guy Debord, conseguimos pensar a cultura como parte da organização na sociedade do espetáculo, pois ela também promove separações por meio de suas manifestações ideológicas, artísticas, identitárias, entre outras, separações estas antes reconhecidas apenas na produção de mercadorias.

A organização burocrática também é muito enfocada na área da Administração. A crítica da burocracia tem nas vertentes revolucionárias de meados do século XX sua maior expressão. Desde autores advindos do grupo Socialismo ou Barbárie (Cornelius Castoriadis, Claude Lefort, Edgar Morin, entre outros) há um pensamento que nega a revolução por meio da tomada do Estado, havendo uma preferência por organizações de base, sem partidos ou sindicatos. Guy Debord compactuava com essa crítica mesmo antes de ter frequentado o Socialismo ou Barbárie. Sua opção pelo conselho de trabalhadores ao invés de partidos e sindicatos é um modo de organização não apenas do trabalho, mas da vida. Com base nele, há uma crítica direta a todas as outras formas que pressupõem a separação hierárquica. A partir do pensamento crítico de Debord, pode-se pensar como cooperativas, coletivos e grupos de economia popular solidária, por exemplo, estão submetidos a uma mesma lógica capitalista, pois são organizados visando à participação no espetáculo.

Tal aproximação teórica com a Administração não é possível com Horkheimer, que, desde a década de 1930, considerava estarem bloqueados os potenciais de emancipação contra o capitalismo (este havia estabilizado seus elementos autodestrutivos, integrado as massas a ele e reprimido todo movimento de contestação) e negava, contra outros marxistas ortodoxos, qualquer conexão necessária entre intelectuais e proletariado (JAY, 1996; NOBRE, 2004). A preservação desse distanciamento do instituto era fundada no reconhecimento de que tal posição seria a precondição para manter a verdadeira postura crítica no trabalho teórico. Isso significava não só autonomia diante da política, da academia, e da cultura de massa, mas de qualquer força social (estudantes radicais ou outra coletividade "negativa" nascente) que clamasse ser a força social legítima da verdadeira transformação (JAY, 1996). Talvez isso proporcione a Debord distintas possibilidades de apropriação na Administração (muito mais relacionadas a uma não apropriação) das de Horkheimer, cujas ideias têm sido debatidas, pelo menos nos textos disponíveis no indexador Spell (LOPES, TINOCO e ARAÚJO, 2012; BATISTA-DOS-SANTOS, ALLOUFA e NEPOMUCENO, 2010), enfatizando a viabilidade da aplicação delas em metodologias e epistemologias críticas da área.

Assim, ao entender o mundo como uma acumulação de espetáculos/separações, Guy Debord mostra que os movimentos sociais estão submetidos a esse mesmo campo de separação. Desse modo, a partir da teoria crítica de Guy Debord, é possível revelar os meandros das organizações que permeiam os movimentos sociais e populares bem como suas verdadeiras intenções. Assim, é possível se pensar a forma organizativa dos movimentos sociais como própria do espetáculo, extrapolando a mera constatação de que suas proposições são reformistas, mas revelando as formas nas quais perpetuam a(s) separação(ões).

Guy Debord propõe a radicalização da teoria crítica, não apenas voltando-a para uma crítica da cultura e da indústria cultural, mas de todos os setores da sociedade. Nesse sentido, Debord se aproxima de Adorno, para quem "a crítica cultural converte-se em fisiognomonia social" (ADORNO, 1998, p. 21), mas diverge de Adorno, pois, para Debord, a preocupação não estava em um lugar distante das lutas cotidianas contra o espetáculo. A integralização promovida pelo espetáculo configura uma nova forma de domínio, não mais restrito ao Estado ou ao mercado apenas, mas a todas as dimensões da vida. A teoria crítica é o modo mais concreto de se resistir até hoje, pois significa negação radical. Guy Debord propõe um novo entendimento da teoria crítica, vista como prática, elaborando-a como tática e estratégia. Para isso, a forma na qual ela é elaborada, seu estilo, tem tanta importância quanto o movimento de negação que ela realiza. A possibilidade de realizar essa discussão sob a perspectiva dos estudos organizacionais pode vir a constituir uma análise interessante. 
Com Guy Debord, podemos entender que as organizações possuem uma dimensão estética, pois estão presentes no espetáculo. A organização é uma manifestação estética por excelência, devido aos apelos sensitivos que produz. Seja na produção e seu ritmo, no desenho da sua forma organizacional ou nos produtos que fabrica. $\mathrm{O}$ entendimento da organização como imagem e, também, produtora de imagens, torna-a passível de estudos estéticos. Essa presença estética da organização na sociedade do espetáculo é passível de crítica específica quando se considera o todo, o espetáculo, bem como sua potência de comunicação com ele. A linguagem com a qual se comunica no espetáculo é espetacular e serve para a promoção da separação generalizada. Desse modo, podemos ampliar os estudos sobre o discurso elaborando relações entre contextos gerais e específicos. Se o gerente pensa a organização, seu discurso sobre ela será feito na linguagem da separação, que é geral na sociedade, e não apenas de sua organização. Podemos estudar de que modo os discursos se repetem ou se inovam inter e intraorganizacionalmente.

Essas são possibilidades variadas de continuar a discussão aqui proposta. Alguns desses estudos já se encontram em desenvolvimento como forma de estabilizar a leitura de Guy Debord nas organizações, outros merecem muito mais tempo de reflexão para que problemas diversos de leitura não decorram de seu desenvolvimento.

\section{Considerações Finais}

A tese deste artigo foi a de que a forma de "utilizar" Debord e sua crítica na Administração serve como crítica à Administração tal como se critica TODO o espetáculo. È possível rever, portanto, a crítica nos estudos organizacionais a partir de três contribuições do pensamento de Guy Debord.

A primeira contribuição é repensar a categoria de espetáculo. Não mais como uma aparência sensorialvisível, situada abaixo de uma realidade verdadeira suprassensível, como é o caso dos estudos avaliados neste artigo, mas a partir das categorias hegelianas aparência (Schein) e aparição (Erscheinung), aplicadas à produção capitalista, que é por onde Marx realizou a crítica ao domínio fetichista do valor (AQUINO, 2007). Isso possibilitaria entender o espetáculo como uma inversão entre o sensível e o suprassensível (do valor econômico), que ganha forma histórica concreta e transforma o sensível e o fenomênico em algo do mesmo modo abstrato (p. ex., no uso social do tempo e do espaço, no lazer mercantil, no consumo de mercadorias etc.). Entender como o automovimento do capital constitui experiência de passividade contemplativa, que substitui o vivido e impõe-se como imagem a ser vista e contemplada por meio de práticas disciplinares cotidianas, abrirá novas temáticas aos estudos organizacionais.

Outra contribuição, inseparável da primeira, diz respeito às relações comunicativas interpessoais. Para Debord, a expropriação da atividade autônoma no trabalho e a expropriação da linguagem comunicativa são duas determinações que se refletem reciprocamente, por ser condição e consequência necessárias da universalização de relações sociais presididas pela lei do valor (AQUINO, 2007). Todavia, uma crítica teórica do capitalismo desenvolvido na qual se encontram articuladas, de modo inseparável, a passividade mercantil e a instrumentação reificada da linguagem, nos termos propostos pelo autor, ainda não ocorreu nos estudos organizacionais brasileiros.

Uma terceira contribuição diz respeito ao tema da linguagem comum em Debord, que também está presente em Walter Benjamin e Georg Lukács. Historicamente, o tema foi inspirado em dois fenômenos contemporâneas do primeiro quarto do século XX, a saber: as experiências anti-hierárquicas do movimento operário e as experiências expressivas da arte moderna (AQUINO, 2007). No âmbito dessa reflexão, entender como certas organizações mantêm a separação entre a dimensão expressiva e comunicativa da linguagem, ao impedir, por exemplo, experiências organizacionais horizontais e anti-hierárquicas, como os conselhos e as assembleias, possui grande valor. Afinal, para Debord, as possibilidades sociais do diálogo e da comunicação nas decisões executórias acerca da vida comum dos homens só existem em uma sociedade liberada do domínio fetichista das formas-valor. Como isso ainda não ocorreu, tal situação deixa em 
suspenso o programa das vanguardas artísticas do início do século XX, que almejava modos de passagem da estética expressiva à práxis social comunicativa nas condições do capitalismo espetacular. Sob essa perspectiva, os estudos organizacionais críticos, ao analisar formas de comunicação que carregam, com radicalidade, um sentido outro de comunicação, poderão realizar positivamente o programa comunicativo que, em negativo, é imanente à arte moderna.

Guy Debord é um autor que transitou por várias áreas do conhecimento e das artes. É possível que afirmar isso não seja o correto, uma vez que o autor se propôs a pensar a sociedade atual e seu modo de produção (inclusive a produção do conhecimento), de forma negativa e não a partir de uma ou outra área do conhecimento. Entretanto, a utilização das variadas tradições para compor uma nova linguagem teve de - e deveria - ser feita a partir do existente, muitas vezes como subversão, deslocamento do lugar, cópias onde não se deveria copiar e repetição do que não se deveria repetir.

Este artigo foi escrito por vermos uma grande dificuldade na incorporação desse autor na área da Administração, pois Debord não apenas negava tudo o que se propaga nas academias, como mas, também, as organizações existentes. Mesmo assim, acreditamos ser necessário haver algum tipo de recepção do autor não apenas nos estudos organizacionais, mas na Administração de um modo geral. Vemos, nos estudos enfocados, a insistência em uma leitura parcial do espetáculo, ignorando o todo, bem como há um entendimento do conceito de espetáculo apenas pelo aspecto midiático, relacionando-o a noções de "cultura de massas", "indústria cultural", "cultura de mídias", entre outros. Ambas as abordagens, sem a devida advertência ao leitor de que ali se faz uma leitura livre da teoria crítica de Guy Debord, invalidam a presença de Guy Debord nos referidos estudos.

Para essa recepção, é importante entendermos as relações entre Guy Debord e diversos outros teóricos, críticos, autores de modo geral que, também, têm muito a contribuir com a área. A relação entre Guy Debord e Walter Benjamin, por exemplo, pode ser vislumbrada no livro Lado B [enjamin] (CARRIERI, GOBIRA e FABRI, 2010). Em Giorgio Agamben $(2002 ;$ 2007c) também podemos ver a relação entre Guy Debord, Benjamin e a sociedade contemporânea. Ao fim e ao cabo, este artigo tratou das possibilidades de recepção coerente de teóricos e críticos contemporâneos da sociedade que ainda não tiveram leituras claras no campo da Administração e, mais especificamente, dos estudos organizacionais.

Além dos já citados, há outros autores que merecem ser pensados no contexto dos estudos organizacionais e da Administração. Slavoj Zizek é um deles, tendo sido discutido em apenas um artigo (FONTENELLE, 2009), encontrado sob o mesmo regime de busca adotado neste estudo. Zizek é responsável por uma controversa - e atual - recepção de Jacques Lacan que realiza uma ponte com a crítica da economia política.

Devemos recorrer também aos estudos de Mario Perniola $(2000 ; 2009)$ e sua análise sobre a estética contemporânea, especialmente o barroco e ao já referido Giorgio Agamben (2007a; 2007b) e sua crítica contundente ao espetáculo como um estado de exceção, em que a ideia de soberania extrapola os domínios do Estado.

Ao iniciarmos uma justa recepção de suas obras, perceberemos que esses autores têm muito a contribuir com os estudos organizacionais e com a Administração, criando um regime diferenciado de discussão da sociedade. Com isso, a área só têm a ganhar. 


\section{Referências}

ADORNO, T. Prismas: crítica cultural e sociedade. São Paulo: Ática. 1998.

ADORNO, T. Indústria cultural e sociedade. São Paulo: Paz e Terra, 2002.

AGAMBEN, G. Glosas marginais aos Comentários sobre a sociedade do espetáculo. 2002. Disponível em: <http://www.scribd.com/doc/46876553/Potlatch-Rizoma-net〉. Acesso em: 25 fev. 2010.

AGAMBEN, G. Estado de exceção. Trad. Iraci D. Poleti. 2. ed. São Paulo: Boitempo, 2007a.

AGAMBEN, G. Homo sacer: o poder soberano e a vida nua. Trad. Henrique Burigo. Belo Horizonte: UFMG, $2007 \mathrm{~b}$. v. 1.

AGAMBEN, G. O cinema de Guy Debord. 2007c. Disponível em: <http://intermidias.blogspot.com/2007/07/o-cinemade-guy-debord-de-giorgio.html>. Acesso em: 12 set. 2008.

ALTHUSSER, L. Aparelhos ideológicos de Estado: nota sobre os aparelhos ideológicos do Estado. Rio de Janeiro: Graal, 2001.

AQUINO, J. E. F. de. Anotações sobre "A sociedade do espetáculo": apresentação de uma edição pirata. In: DEBORD, G. A sociedade do espetáculo. Belo Horizonte: Coletivo Acrático Proposta, 2003. 79-93 p. Disponível em: <http://www.scribd.com/doc/46876553/Potlatch-Rizoma-net>. Acesso em: 25/01/2014.

AQUINO, J. E. F. Linguagem e reificação em André Breton e Guy Debord. 263 f. Tese (Doutorado em Filosofia) Pontifícia Universidade Católica de São Paulo, São Paulo, 2005.

AQUINO, J. E. F. Reificação e linguagem em Guy Debord. Fortaleza: Ed. Uece/Unifor, 2006.

AQUINO, J. E. F. Espetáculo, comunicação e comunismo em Guy Debord. Kriterion: Revista de Filosofia, v. 48, n. 115, p. 167-182, 2007. Disponível em: <http://www.scielo.br/pdf/kr/v48n115/a1048115.pdf>. Acesso em: 10 out. 2009.

BATISTA-DOS-SANTOS, A. C.; ALLOUFA, J. M.; NEPOMUCENO, L. H. Epistemologia e metodologia para as pesquisas críticas em administração: leituras aproximadas de Horkheimer e Adorno. Revista de Administração de Empresas, v. 50, n. 3, p. 312-324, jul./set. 2010.

BENJAMIN, W. A obra de arte na era da sua reprodutibilidade técnica. In: BENJAMIN, W. Obras escolhidas: magia e técnica, arte e política. Trad. Sérgio Paulo Rouanet. São Paulo: Brasiliense, 1994. v. 1. 165-196 p.

BUCK-MORSS, S. The origin of negative dialectics: Theodor W. Adorno, Walter Benjamin and the Frankfurt Institute. New York: Free Press, 1977.

CAMNITZER, L. Didáctica de la liberación: arte conceptualista latinoamericano. Montevideo: HUM/CCE/CCEBA, 2008.

CARRIERI, A. P.; GOBIRA, P.; FABRI, B. Lado B[enjamin]. Belo Horizonte: Crisálida, 2011.

CASTELO, M. G.; CARVALHO, L. F. S. Reality shows e jogos (hiper)reais do espetáculo organizacional. In: ENCONTRO NACIONAL DE ESTUDOS ORGANIZACIONAIS, 3., 2004, Atibaia. Anais... Atibaia, SP: Anpad, 2004. $1-16 \mathrm{p}$.

COOK, D. The culture industry revisited. London: Rowman \& Littlefield, 1996.

CORREIA, J. A. Para uma teoria crítica em educação. Porto: Porto Ed., 1998. 
DEBORD, G. Report on the construction of situations and on the International Situationist tendency's conditions of organization and action. 1957. Disponível em: <http://www.cddc.vt.edu/sionline/si/report.html>. Acesso em: 29 set. 2014.

DEBORD, G. A sociedade do espetáculo: comentários sobre a sociedade do espetáculo. Trad. Estela dos Santos Abreu. Rio de Janeiro: Contraponto, 1997.

DEBORD, G. Panegírico. Trad. Edison Cardoni. São Paulo: Conrad, 2002. v. 1.

DEBRAY, R. Debord de longe: resposta a um jovem pesquisador. In: DEBRAY, R. Acreditar, ver, fazer. Trad. Eliana Maria de Melo Souza. Bauru, SP: Ed. USC, 2003. 103-115 p.

ECO, U. Apocalípticos e integrados. 5. ed. São Paulo: Perspectiva, 1993.

FONTENELLE, I. A. O lugar vazio da crítica: ideologia e transformação em Slavoj Zizek. In: ENCONTRO NACIONAL DA ASSOCIAÇÃO NACIONAL DE PÓS-GRADUAÇÃO E PESQUISA EM ADMINISTRAÇÃO, 33. 2009, São Paulo. Anais... São Paulo: Anpad, 2009. 1-13 p.

FREDERICO, C. Debord: do espetáculo ao simulacro. MATRIZes, v. 4, n. 1, p. 179-191, jul./dez. 2010.

FREITAG, B. A teoria crítica. Ontem e hoje. 5. ed. São Paulo: Brasiliense, 2004.

GALLIX, A. The resurrection of Guy Debord. 2009. Disponível em: <http://www.guardian.co.uk/books/booksblog/2009/mar/18/guy-debord-situationist-international>. Acesso em: 30 abr. 2010.

HARDT, M. Multidão: guerra e democracia na Era do Império. Rio de Janeiro: Record, 2005.

HARDT, M.; NEGRI, A. Império. Trad. Berilo Vargas. 2. ed. Rio de Janeiro: Record, 2001.

HONNETH, A. Teoria crítica. In: GIDDENS, A.; TURNER, J. (Org.). Teoria social hoje. Trad. Gilson César Cardoso de Sousa. São Paulo: Ed. Unesp, 1999. 503-552 p.

HORKHEIMER, M. Filosofia e teoria crítica. In: HORKHEIMER, M. et al. Textos escolhidos: Benjamin, Horkheimer, Adorno, Habermas. Trad. Edgard Afonso Malagodi e Ronaldo Pereira Cunha. São Paulo: Abril Cultural, $1983 a .155$ 161 p. (Os Pensadores).

HORKHEIMER, M. Teoria tradicional e teoria crítica. In: HORKHEIMER, M. et al. Textos escolhidos: Benjamin, Horkheimer, Adorno, Habermas. Trad. Edgard Afonso Malagodi e Ronaldo Pereira Cunha. São Paulo: Abril Cultural, 1983b. 117-154 p. (Os Pensadores).

INTERNACIONAL SITUACIONISTA. All the king's men. 1967. Disponível em: <http://www.bopsecrets.org/SI/8.kingsmen.htm>. Acesso em: 30 set. 2014.

JAPPE, A. A arte de desmascarar: um dos principais libelos contra o capitalismo, "A sociedade do espetáculo". Folha de S. Paulo, 17 ago. 1997. Caderno MAIS!. 4-5 p.

JAPPE, A. Guy Debord. Petrópolis, RJ: Vozes, 1999.

JAY, M. Marxism and totality: the adventures of a concept from Lukács to Habermas. Cambridge: Polity Press, 1984.

JAY, M. The dialectical imagination: a history of the Frankfurt School and the Institute of Social Research $1923-$ 1950. Berkeley, CA: University of California Press, 1996.

KLEIN, N. Sem logo: a tirania das marcas em um planeta vendido. Rio de Janeiro: Record, 2002. 
KURZ, R. A sociedade do espetáculo trinta anos depois. 1999 . Disponível em: <http://obeco.planetaclix.pt/rkurz98.htm>. Acesso em: 27 nov. 2010.

LE MAGAZINE LITTÉRAIRE. Les archives de Guy Debord à la BnF. 2011. Disponível em: <http://www.magazine-litteraire.com/content/newsletter_actualite-ecrivain/article.html?id=18600>. Acesso em: 24 fev. 2011.

LOPES, A.; TINOCO, D.; ARAÚJO, R. Turismo como vetor de desenvolvimento local: um olhar através das ideias de Theodor Adorno e Max Horkheimer. Revista Turismo em Análise, v. 23, n. 1, p. 104-127, jan./abr. 2012.

LUKÁCS, G. História e consciência de classe: estudos sobre a dialética marxista. Trad. Rodnei Nascimento. São Paulo: Martins Fontes, 2003

MAGALHÃES, I. Teoria crítica do discurso e texto. Linguagem em (Dis)curso, v. 4, n. Edição especial, p. 113-131, 2004.

MARX, K. O capital: crítica da economia política. Trad. Reginaldo Sant'Anna. Rio de Janeiro: Civilização Brasileira, 2003. v. 1.

MATOS, O. C. F. Paris 1968: as barricadas do desejo. São Paulo: Brasiliense, 1981.

MENEGHETTI, F. K.; CICMANEC, É. Ideologia e espetacularização nas práticas discursivas gerenciais em uma loja de departamentos. In: ENCONTRO NACIONAL DA ASSOCIAÇÃO NACIONAL DE PÓS-GRADUAÇÃO E PESQUISA EM ADMINISTRAÇÃO, 34., 2010, Rio de Janeiro. Anais... Rio de Janeiro: Anpad, 2010. 1-17 p.

NOBRE, M. Lukács e o materialismo interdisciplinar, uma leitura de teoria tradicional e teoria crítica, de Horkheimer. In: ANTUNES, R.; REGO, W. L. (Org.). Lukács, um Galileu no século XX. São Paulo: Boitempo, 1996. 74-83 p.

NOBRE, M. Lukács e os limites da reificação: um estudo sobre história e consciência de classe. São Paulo: Ed. 34, 2001.

NOBRE, M. A teoria crítica. Rio de Janeiro: Jorge Zahar, 2004.

NOBRE, M. Max Horkheimer: a teoria crítica entre o nazismo e o capitalismo tardio. In: NOBRE, M. (Org.). Curso livre de teoria crítica. Campinas, SP: Papirus, 2008. 35-52 p.

PANNEKOEK, A. Worker's $\quad$ councils. $1936 . \quad$ Disponível em: <http://www.marxists.org/archive/pannekoe/1936/councils.htm>. Acesso em: 10 abr. 2009.

PANNEKOEK, A. Worker's councils: tasks. $1947 . \quad$ Disponível em: <http://www.marxists.org/archive/pannekoe/1947/workers-councils.htm>. Acesso em: 10 abr. 2009.

PAULA, A. P. P. Teoria crítica nas organizações. São Paulo: Thomson, 2007.

PERNIOLA, M. Pensando o ritual: sexualidade, morte, mundo. Trad. Maria do Rosário Toschi. São Paulo: Studio Nobel, 2000.

PERNIOLA, M. Jean Baudrillard. El futuro de una ilusión: acción artística, comunicación, patafísica. Archipiélago, n. 79, p. 79-90, dez. 2007.

PERNIOLA, M. Enigmas: egípcio, barroco e neobarroco na sociedade e na arte. Trad. Carolina Pizzolo. Chapecó: Argos, 2009.

RIBEIRO, R. J. Feitiçarias do capital. Folha de S. Paulo, São Paulo. 17 ago. 1997. Caderno +Mais! Disponível em: < http://www1.folha.uol.com.br/fsp/mais/fs170810.htm> Acesso em 15 jan. 2014.

RYOKI, A.; ORTELLADO, P. Estamos vencendo! Resistência global no Brasil. São Paulo: Conrad: 2004. 
SCOCUGLIA, J. B. C. Território, cultura contemporânea e urbanidade: refletindo sobre práticas urbanas, espaço público e planejamento. In: EGLER, T. T. C. Reinvenção da democracia na América Latina. Rio de Janeiro: Letra Capital, 2013. 163-194 p.

SOARES, E. A. L. O espetáculo como estratégia do marketing político. In: ENCONTRO NACIONAL DA ASSOCIAÇÃO NACIONAL DE PÓS-GRADUAÇÃO E PESQUISA EM ADMINISTRAÇÃO, 32., 2008, Rio de Janeiro. Anais... Rio de Janeiro: Anpad, 2008. 1-14 p.

SOUZA, P. R. B.; SALDANHA, A. N. K.; ICHIKAWA, E. Y. Teoria crítica na administração. Caderno de Pesquisas em Administração, v. 11, n. 3, p. 1-9, jul./set. 2004.

VIRNO, P. Gramática da multidão: para uma análise das formas de vida contemporâneas. 2003. Disponível em: <http://api.ning.com/files/WEhh*WfqWwJnfrxX0t6XxXPIiFIRblb-

JSWxRuVovhbRbroYNoIA1Nowb2RVc7M0BpxXQ-

vvFgN3ewEzZu8w1b2hW1ThRWjQ/GRAMTICADAMULTIDO.pdf>. Acesso em: 14 set. 2010.

WIGGERSHAUS, R. The Frankfurt School: its history, theories, and political significance. Cambridge, MA: The MIT Press, 1998.

WOOD JR., T. Metáforas espetaculares: do dramatismo teatral ao dramatismo cinematográfico. In: ENCONTRO NACIONAL DA ASSOCIAÇÃO NACIONAL DE PÓS-GRADUAÇÃO E PESQUISA EM ADMINISTRAÇÃO, 24., 2000, Florianópolis. Anais... Florianópolis: Anpad, 2000. 1-16 p. 